\title{
Portland clinker with civil construction waste: influence of pellet geometry on the formation of crystalline phases
}

\author{
Clínquer Portland com resíduo de construção civil: \\ influência da geometria do pellet na formação das fases \\ cristalinas
}

\section{Fernanda Nepomuceno Costa \\ Daniel Véras Ribeiro \\ Cléber Marcos Ribeiro Dias}

\begin{abstract}
$\mathbf{E}$

fforts to reduce greenhouse gas emissions in the context of sustainable development have intensified, with the development of research aimed at the production of new materials and binders for construction. This article analyzes the influence of pellet geometry in the production of clinkers, with the incorporation of construction waste (CCW). Procedures adapted from the method proposed by Brazilian Portland Cement Association were adopted in studies of laboratory clinkers, in an attempt to simulate the stages of the industrial process. Pellets were prepared with the same formulation, however, with four different geometries: spherical, with diameters of $1 \mathrm{~cm}, 2 \mathrm{~cm}$ and $3 \mathrm{~cm}$, with manual molding, and semi-spherical, with a diameter of $2 \mathrm{~cm}$, using molds of PLA (polylactic acid) printed on a 3D printer to facilitate the molding of the clinkers in a standardized way. Clinkers were characterized mineralogically by x-ray diffraction (XRD) and the Rietveld method was used to quantify the phases. Variations in the quantities of the alite and belite phases were observed depending on the geometry of the pellets, although the same calcination conditions were used. This is probably due to the variation in the surface area (exposure area) and the gradients of the cooling rate.

Keywords: CCW. Spherical pellets. Semi-spherical pellets. 3D printed mold. Production procedure.

\section{Resumo}

Intensificaram-se os esforços para a redução das emissões de gases do efeito estufa no contexto do desenvolvimento sustentável, com o desenvolvimento de pesquisas, visando a produção de novos materiais e ligantes para a construção. Esse artigo analisa a influência da geometria dos pellets, na produção de clínqueres, com a incorporação de resíduo da construção civil (RCC). Foram adotados procedimentos adaptados da metodologia proposta pela $A B C P e$

Fernanda Nepomuceno Costa 1 Universidade Federal da Bahia Salvador - BA - Brasil

${ }^{2}$ Daniel Véras Ribeiro ZUniversidade Federal da Bahia Salvador - BA - Brasil

${ }^{3}$ Cléber Marcos Ribeiro Dias 3 Universidade Federal da Bahia Salvador - BA - Brasil

Recebido em 23/01/20

Aceito em 01/06/20

adotada em estudos de clínqueres laboratoriais, na tentativa de simular etapas do processo industrial. Pellets foram preparados com a mesma formulação, porém, com quarto diferentes geometrias: esféricos, com diâmetros de $1 \mathrm{~cm}$, de $2 \mathrm{~cm}$ e de $3 \mathrm{~cm}$, com modelagem manual, e semi-esféricos, com diâmetro de $2 \mathrm{~cm}$, empregando-se moldes de PLA (ácido polilático) impressos em impressora 3D, que facilitaram a moldagem dos clínqueres de forma padronizada. Os clínqueres foram caracterizados mineralogicamente por difração de raios $x(D R X)$ e o método de Rietveld foi empregado na quantificação das fases. Observaram-se variações nas quantidades das fases alita e belita em função da geometria dos pellets, embora tenham sido utilizadas as mesmas condições de calcinação, provavelmente devido à variação da área superficial (área de exposição) e a gradientes da taxa de resfriamento.

Palavras-chave: RCC. Pellets esféricos. Pellets semi-esféricos. Molde impresso em 3D. Procedimento de produção.
\end{abstract}




\section{Introduction}

In recent years, there has been a global effort to find solutions to reduce greenhouse gas emissions exploiting natural resources and inadequate waste disposal, with the development of new materials and binders for construction. In Brazil, in 2018, approximately 43.3 million tons of solid urban waste $(59.5 \%$ of the total collected) was disposed of in landfills (ASSOCIAÇÃO..., 2020). The rest $(40.5 \%)$ was dumped in inappropriate places, such as dumps or controlled landfills, with a high potential for environmental pollution and negative impacts on health (ASSOCIAÇÃO..., 2020).

Civil construction waste $(\mathrm{CCW})$, which represents about $56 \%$ of urban solid waste (ASSOCIAÇÃO..., 2020), offers many opportunities for reuse. Several studies have reported positive results indicating the technical feasibility of using construction waste in various ways, mainly to replace natural aggregates (GUO et al., 2018; BUI; SATOMI; TAKAHASHI, 2018; AMORIM JÚNIOR et al., 2019; BOGAS; CARRIÇO; PEREIRA, 2019) and as a complementary cementitious material (KIM; CHOI, 2012; ASENSIO et al., 2016; LETELIER et al., 2017; CANTERO et al., 2019) in concretes and mortars. These wastes have been tested in the manufacture of cement, replacing part of the conventional raw materials (limestone and clay) of Portland clinker (GALBENIS; TSIMAS, 2006; PUERTAS et al., 2008; SCHOON et al., 2015; KIM; TAE; KIM, 2018) or be used as an addition, replacing part of the clinker in the final cement composition (AY; ÜNAL, 2000; SHAH; BISHNOI, 2015; RUIZ-SÁNCHEZ; SÁNCHEZ-POLO; ROZALEN, 2019).

Thus, in the various proposals for alternatives, the incorporation of industrial wastes and/or by-products in the cement industry stands out as promising to minimize environmental impacts, such as reducing $\mathrm{CO}_{2}$ generation, energy consumption and extraction of natural material.

Portland cement is a hydraulic binder resulting from the grinding of Portland clinker, product of the calcination of a mixture of limestone $\left(\mathrm{CaCO}_{3}\right)$ and clay, in a rotary kiln, with a temperature of around 1450 ${ }^{\circ} \mathrm{C}$, and with the addition of calcium sulfate to regulate the time beginning of hydration of cement components (WINTER, 2012). Portland clinker contains four main minerals, also called crystalline phases: alite $\left(3 \mathrm{CaO} . \mathrm{SiO}_{2}\right)$, belite $\left(2 \mathrm{CaO} \cdot \mathrm{SiO}_{2}\right)$, tricalcium aluminate $\left(3 \mathrm{CaO} \cdot \mathrm{Al}_{2} \mathrm{O}_{3}\right)$ and tetracalcium ferroaluminate $\left(4 \mathrm{CaO} \cdot \mathrm{Al}_{2} \mathrm{O}_{3} \cdot \mathrm{Fe}_{2} \mathrm{O}_{3}\right)$, complemented with a variable number of minor phases (LUDWIG; ZHANG, 2015; SNELLINGS, 2016).

$\mathrm{CCW}$ appears as an alternative source of the main chemical elements of Portland clinker $\left(\mathrm{CaO}, \mathrm{SiO}_{2}, \mathrm{Al}_{2} \mathrm{O}_{3}\right.$ and $\mathrm{Fe}_{2} \mathrm{O}_{3}$ ), allowing the introduction of $\mathrm{CaO}$ in the raw mix formulation, partially replacing the usual raw materials and, thus, reducing $\mathrm{CO}_{2}$ emissions during clinker (GALBENIS; TSIMAS, 2006; PUERTAS et al., 2006; SCHOON et al., 2015). Thus, the modification of the CCW by beneficiation processes and / or its use as an integral part of the raw mix in the cement industry stands out as an interesting alternative, since the $\mathrm{CCW}$ undergoes transformations from the mineralogical point of view, during clinker, together with other raw materials, and gives rise to a cementitious product with properties similar to Portland clinker.

Previous studies have been developed aiming at the manufacture of Portland cement clinker using construction waste as an alternative raw material. It is observed that in the highlighted works, different conditions of composition of the $\mathrm{CCW}$ were considered, that is, in some studies only recycled concrete wastes were used (GALBENIS; TSIMAS, 2006; NOBRE; GUERREIRO; KIRCHHEIM, 2015), in other wastes of ceramic tiles (PUERTAS et al., 2006) and, still, wastes of ceramic tiles (PUERTAS et al., 2008). That is, the surveys adopted CCW selected according to their research interest. In this work, a different approach was given to the use of $\mathrm{CCW}$ when considering all parts of the constituents of class A civil construction waste of CONAMA Resolution No. 307 (CONSELHO..., 2002), through the use of its thin part.

Since cement is a material with high consumption worldwide and with projections of growing demand, the interest in the theme and the initiatives for studies and research is still very high (SCRIVENER; HOHN; GARTNER, 2018; GARTNER; SUI, 2018; REN et al., 2020). Estimates indicate that cement production globally returned to 4.1 gigaton in 2018, an increase of $1 \%$ after annual drops of $1 \%$ in the period 2014-2017 (UNITED..., 2019).

Thus, the use of solid industrial waste in the production of cement induces the development of research and laboratory experiments that require rigorous criteria, most of the time with techniques on a small scale, to simulate the stages of industrial production, that is, the use of experimental techniques with miniature samples. Beaudoin (2001) cites a number of advantages of adopting small-scale tests, such as: material savings, especially when material is unavailable, cost reduction with equipment and supplies, space and time savings required to obtain the results, safety for handling smaller samples, in addition to less waste 
generation with the tests. Also, test preparation and execution procedures may have fewer steps or be simpler.

Several researchers have developed clinker studies, using different experimental methods, in an attempt to simulate industrial processing (ANDRADE; KIHARA; MARINGOLO, 2003; COSTA et al., 2013; MARIANI et al., 2019). The production parameters used include the geometry and mass of the clinker pellets. Table 1 presents information about some research developed in the last two decades, using different wastes to produce clinker. It highlights the shape of the molding and the geometry of the pellets in the different studies. There is variability in the pellet production methods used, which makes it difficult to compare the different clinkers produced in different ways.

However, there is an absence of studies that evaluate how the geometric characteristics of the pellet (size and format) influence the formation of crystalline phases on the clinker, since the variation in the surface area and mass influences the efficiency of the process parameters, such as the firing rate and cooling rate gradient. In addition, many published studies do not present details about clinkers conformation, omitting important information (TREZZA; SCIAN, 2007; SIMÃO et al., 2018). This work analyzed the influence of the pellet geometry on the production of Portland clinkers with the incorporation of $\mathrm{CCW}$, according to crystalline phases formation.

\section{Materials and methods}

\section{Materials}

For the development of this research and production of clinkers, samples of CCW class A were used, that is, reusable or recyclable waste in the form of aggregates (CONSELHO..., 2002). These wastes, used in the present study as they are marketed, come from the Waste Recovery Unit Grajau S.A. (WRUG), located in the city of São Paulo (Brazil). Limestone and clay samples were also used, provided by a cement company located in the state of Sergipe.

Table 1 - Information about the shape of the molding and geometry of the pellets used by some researchers in the last two decades, using different wastes to produce clinker

\begin{tabular}{|c|c|c|c|}
\hline Reference & Alternative Material Used & Molding & Pellet Geometry \\
\hline $\begin{array}{l}\text { Andrade, Kihara and } \\
\text { Maringolo (2003) }\end{array}$ & $\begin{array}{c}\text { Metals }(\mathrm{V}, \mathrm{Zn}, \mathrm{Pb}) \text { present in coal, } \\
\text { petcoke and tires }\end{array}$ & Manual & $\begin{array}{c}\text { Spherical } \\
(\phi=1 \mathrm{~cm})\end{array}$ \\
\hline Tsakiridis et al. (2008) & Steel slag & Manual & $\begin{array}{l}\text { Spherical } \\
(\phi=2 \mathrm{~cm})\end{array}$ \\
\hline Puertas et al. (2010) & $\begin{array}{l}\text { Ceramic waste } \\
\text { (red and white) }\end{array}$ & Manual & $\begin{array}{c}\text { Spherical } \\
(\phi=3 \mathrm{~cm}), \mathrm{m}=4 \mathrm{~g}\end{array}$ \\
\hline $\begin{array}{c}\text { Nobre, Guerreiro and } \\
\text { Kirchheim (2015) }\end{array}$ & $\begin{array}{c}\text { Lab Concrete with ladle furnace } \\
\text { slag and agate waste }\end{array}$ & Manual & $\begin{array}{c}\text { Spherical } \\
(\phi=1-1.5 \mathrm{~cm})\end{array}$ \\
\hline Costa et al. (2013) & Ladle furnace slag & Manual & $\begin{array}{c}\text { Spherical } \\
(\phi=1 \mathrm{~cm}), \mathrm{m}=3 \mathrm{~g}\end{array}$ \\
\hline Costa (2013) & Aluminum anodizing sludge & Mold & $\begin{array}{c}\text { Semi-ellipsoidal, } \\
\mathrm{m}=1.2 \mathrm{~g}\end{array}$ \\
\hline Vilaplana et al.(2015) & Ladle furnace slag & $\begin{array}{c}\text { Mold }+ \\
10 \text { tons }\end{array}$ & $\begin{array}{c}\text { Prismatic } \\
\left(50 \times 50 \times 15 \mathrm{~mm}^{3}\right)\end{array}$ \\
\hline $\begin{array}{l}\text { Tsakiridis, Samouhos } \\
\text { and Perraki (2017) }\end{array}$ & Dried olive pomace & Manual & $\begin{array}{c}\text { Spherical } \\
(\phi=2 \mathrm{~cm})\end{array}$ \\
\hline $\begin{array}{l}\text { Chen, Chang and Ko } \\
\text { (2017) }\end{array}$ & Desulfurization slag & $\begin{array}{l}\text { Mold + } \\
9.8 \mathrm{MPa}\end{array}$ & $\begin{array}{c}\text { Cylindrical } \\
(\phi=3.5 \mathrm{~cm} \times \mathrm{h}=0.8 \mathrm{~cm})\end{array}$ \\
\hline Mariani et al. (2019) & $\begin{array}{l}\text { Waste generated by production of } \\
\mathrm{TiO}_{2} \text { pigment }\end{array}$ & Manual & $\begin{array}{c}\text { Spherical } \\
(\phi=1 \mathrm{~cm})\end{array}$ \\
\hline
\end{tabular}


Figure 1 - (a) Process flowchart of CCW beneficiation and (b) CCW recovery plant illustration.

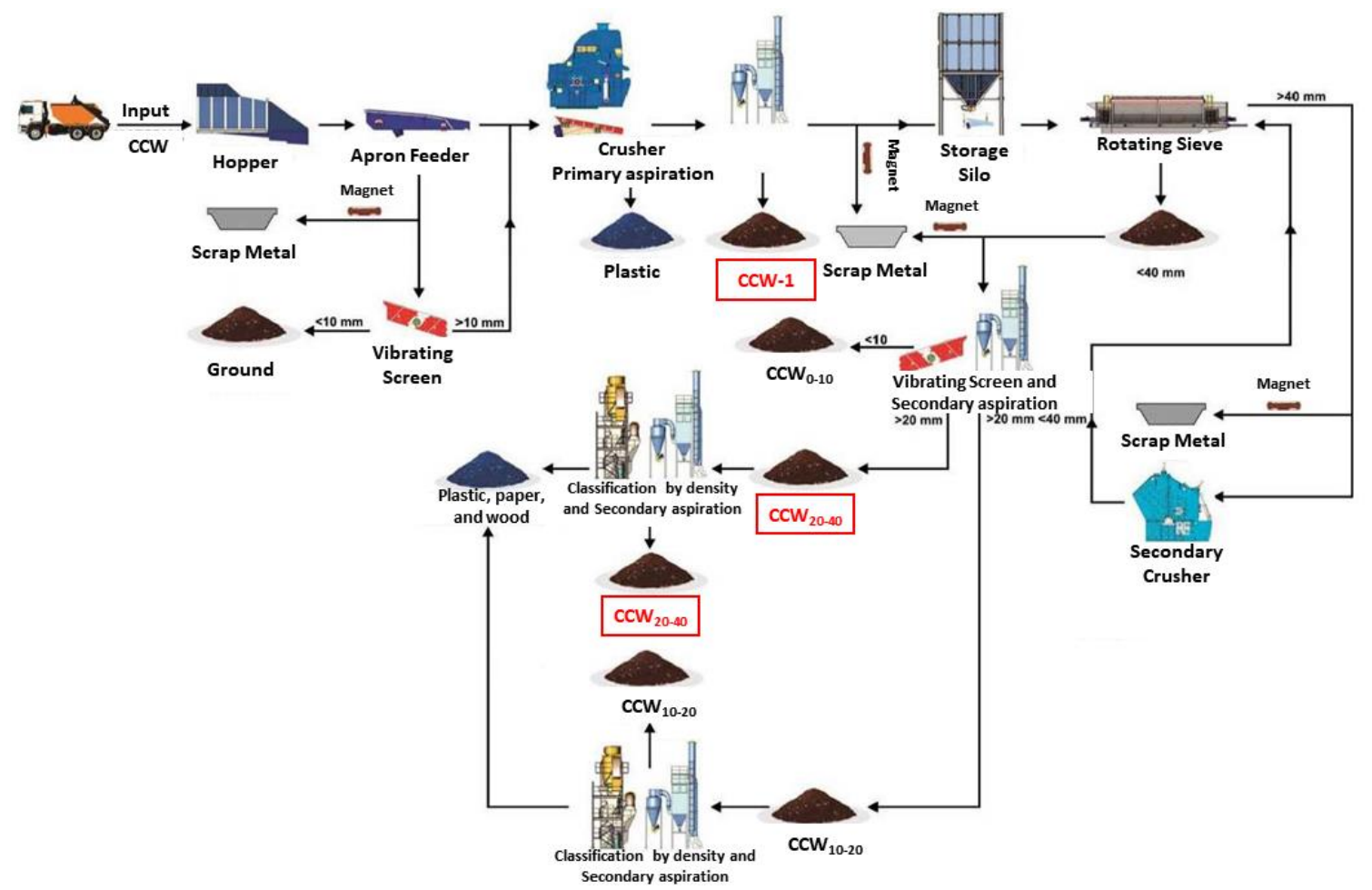

(a)

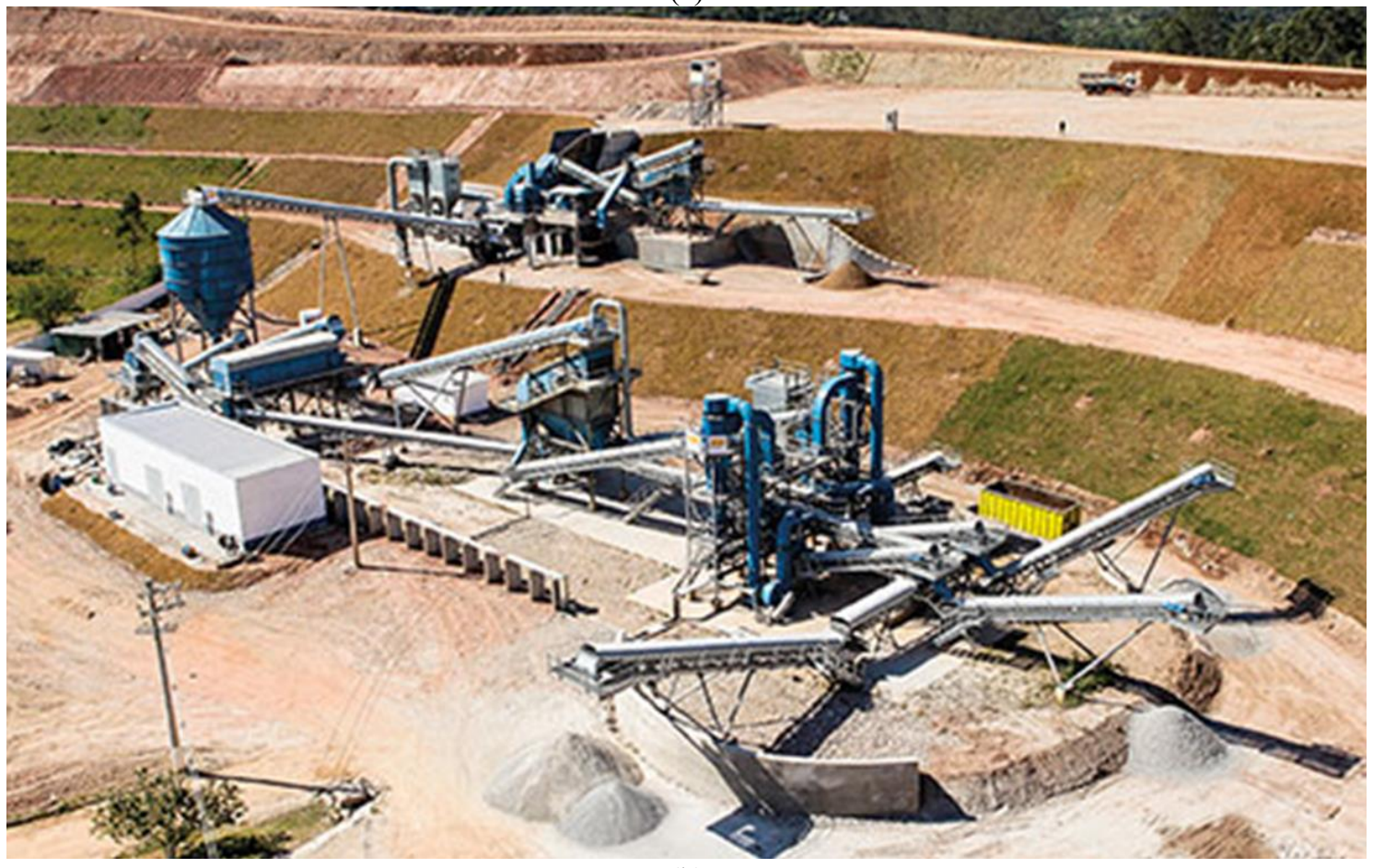

(b)

Figure 1 shows a scheme of the waste processing system and a partial view of the equipment at the plant. Upon receiving the $\mathrm{CCW}$, WRUG performs a pre-screening, in order to remove unwanted materials, such as metals, plaster, paper and other materials of dimensions close to or greater than the hopper's feed limit. In this stage, predominantly wood and materials of large dimensions are removed, and subsequently stored in Roll-on/Roll-off buckets. After pre-screening, the CCW goes to a magnetic separation unit and a low-density 
material removal unit using airflow, and the material is then poured into a primary hopper (AMORIM JÚNIOR et al., 2019).

CCW beneficiation process continues through a vibrating sieve, in which, due to particle size differences, the waste is separated into two streams, one for particles larger than $10 \mathrm{~mm}$ and the other for particles smaller than $10 \mathrm{~mm}$, called scalp, containing predominantly soil in its composition. Particles with diameters greater than $10 \mathrm{~mm}$ are deposited directly in the primary crusher for processing. At that time, a powdery material, known as fine civil construction waste, is generated, which is separated from the rest of the material by means of a cyclone filter, taking it to storage bays.

The remaining material undergoes a new screening, in order to obtain the $\mathrm{CCW}$ with dimensions less than $40 \mathrm{~mm}$. The material that is retained in this screening process is crushed and sieved again. Finally, the material with dimensions less than $40 \mathrm{~mm}$, when falling on the third sieve, is separated into three fractions, of different dimensions: between 0 and $10 \mathrm{~mm}, 10$ and $20 \mathrm{~mm}$ and 20 and $40 \mathrm{~mm}$ (SILVA, 2017).

In this research, two samples of fine fractions of the construction waste $(\mathrm{CCW})$ from WRUG were used, one from the initial stage of waste handling, separated from the other fractions by the action of a cyclone filter, being identified as CCW-1 (powdery material), and another sample from the grinding of CCW grains passing through $40 \mathrm{~mm}$ sieves and retained in the $20 \mathrm{~mm}$ sieve, and identified as $\mathrm{CCW}_{20-40}$. After manual separation and weighing of the different constituents in a representative sample, the $\mathrm{CCW}_{20-40}$ fractions were composed by concrete $(57 \%)$, mortar $(34 \%)$, rock $(7 \%)$, and ceramic $(2 \%)$.

\section{Methods}

\section{Preparation and characterization of raw materials}

Four different lots of each type of CCW were homogenized and had samples selected by means of quarting, obtaining about $50 \mathrm{~kg}$ of material. Then, the grains were ground, using a jaw mill available at the Structures Laboratory of the Federal University of Bahia (Timoshenko) and subsequently in a horizontal ceramic ball mill, until the desired granulometry was reached, namely less than $75 \mu \mathrm{m}$. The limestone and clay samples were also ground into particles below $75 \mu \mathrm{m}$.

Raw materials were characterized physically, chemically and mineralogically. The physical characterization of the $\mathrm{CCW}$ included the evaluation of the specific mass (Micromeritics AccuPyc II 1340 helium pycnometer), the specific BET surface area (Gemini VII 2390a Micromeritics) and the particle size distribution (Mastersizer 2000 Malvern Panalytical laser granulometer, available at Construction Materials Laboratory of the State University of Feira de Santana).

The determination of the chemical composition of the $\mathrm{CCW}$, clay and limestone samples were carried out using the x-ray fluorescence spectroscopy (XRF) technique with a Bruker spectrophotometer, model S2 Ranger, available at the Materials Characterization Laboratory of the Federal Institute of Bahia.

$\mathrm{CCW}$, clay and limestone were characterized mineralogically by $\mathrm{x}$-ray diffraction (XRD), using a D2 Phaser diffractometer (Bruker), with a copper target tube (K $\alpha$ radiation with a wavelength of $1.54060 \AA)$ of $30 \mathrm{kV}$ and $10 \mathrm{~mA}$, without filtering system with secondary monochromator. The diffraction spectra were obtained for $2 \theta$ between $5^{\circ}$ and $90^{\circ}$, using the scan in increments of $0.02^{\circ}$ and collection time of $0.2 \mathrm{~s} / \mathrm{step}$. The phases present in the samples were identified with the aid of the DIFFRAC plus - EVA software, with a database centered on the COD system (Crystallography Open Database).

\section{Dosing and Production of Clinkers}

From the results of characterization of the samples, three dosages of clinker flours (raw mix) were carried out. Two clinker dosages incorporated $\mathrm{CCW}$, replacing the clay and part of the limestone. Additionally, a clinker was dosed with traditional raw materials, without $\mathrm{CCW}$, to be used as a reference.

The main procedures adopted for the production of clinkers were used by other researchers (ANDRADE; KIHARA; MARINGOLO, 2003; COSTA et al., 2013, 2016; MARIANI et al., 2019), according to the methodology proposed by the Brazilian Portland Cement Association (BPCA), in an attempt to simulate the stages of the industrial process. This involves: grinding and homogenization of raw materials, precalcination of raw mix, calcination of clinker and sudden cooling.

Raw mixes with different compositions were dosed, one containing CCW and the other reference, containing only clay and limestone, using the lime saturation factor (LSF) (Equation 1), alumina modulus (AM) (Equation 2) and the silica modulus (SM) (Equation 3) (TAYLOR, 1997). 


$$
\begin{array}{lr}
L S F=\frac{100 \mathrm{CaO}}{2,8 \mathrm{SiO}_{2}+1,18 \mathrm{Al}_{2} \mathrm{O}_{3}+0,65 \mathrm{Fe}_{2} \mathrm{O}_{3}} & \text { Eq. } 1 \\
S M=\frac{\mathrm{SiO}_{2}}{\mathrm{Al}_{2} \mathrm{O}_{3}+\mathrm{Fe}_{2} \mathrm{O}_{3}} & \text { Eq. } 2 \\
A M=\frac{\mathrm{Al}_{2} \mathrm{O}_{3}}{\mathrm{Fe}_{2} \mathrm{O}_{3}} & \text { Eq. } 3
\end{array}
$$

LSF relates the concentration of $\mathrm{CaO}$ present in the clinker raw mix with the other compounds with which it reacts. Expressed in percentage, this indicator determines the maximum amount of calcium oxide that can react with the other constituent oxides as well as the content of the clinker alite $\left(\mathrm{C}_{3} \mathrm{~S}\right)$ (WINTER, 2012). This property is very important, since the degree of clinker burning is indicated by the amount of $\mathrm{CaO}$ that did not react, that is, free lime (AY; ÜNAL, 2000). The increase in the amount of $\mathrm{C}_{3} \mathrm{~S}$ improves the initial strength of the cement and, therefore, the LSF needs to be high enough to produce cement with a high $\mathrm{C}_{3} \mathrm{~S}$ content (WALENTA; FÜLLMANN, 2004).

LSF value of 98 was adopted, according to recent research (RODRÍGUEZ et al., 2013; BURUBERRI; SEABRA; LABRINCHA, 2015; VILAPLANA et al., 2015; MARIANI et al., 2019), in order to obtain clinkers with higher content of alite and lower content of free lime and the incorporation of CCW, replacing all the clay and part of the limestone. With the adoption of fixed LSF, the values of AM and SM were calculated in each of the dosages.

The SM relates the $\mathrm{SiO}_{2}$ concentration to the sum of the $\mathrm{Al}_{2} \mathrm{O}_{3}$ and $\mathrm{Fe}_{2} \mathrm{O}_{3}$ concentrations, that is, it is the ratio of non-melting materials (silicates) and melting materials. The increase in SM generates an increase in the proportion of $\mathrm{C}_{2} \mathrm{~S}$ and $\mathrm{C}_{3} \mathrm{~S}$ and a decrease in the amount of $\mathrm{C}_{3} \mathrm{~A}$ and $\mathrm{C}_{4} \mathrm{AF}$, while low $\mathrm{SM}$ provides an increase in the liquid phase, benefiting the burning (FAURE et al., 2019).

AM represents the relationship between the concentration of $\mathrm{Al}_{2} \mathrm{O}_{3}$ and $\mathrm{Fe}_{2} \mathrm{O}_{3}$, that is, it is the relationship between the two main fluxing materials. The low AM makes the liquid phase less viscous, facilitates reaction kinetics and improves clinker granulation. On the other hand, the high AM increases the proportion of $\mathrm{C}_{3} \mathrm{~A}$ and the viscosity of the liquid phase, hindering the kinetics of chemical reactions (KIM; TAE; KIM, 2018).

Pellets were molded in four different configurations, however, with the same dosage of the raw materials and with the addition of $20 \%$ (by mass) of water, in order to facilitate the molding of these spheres. These are:

(a) spherical pellet with $1 \mathrm{~cm}$ in diameter;

(b) spherical pellet with $2 \mathrm{~cm}$ in diameter;

(c) spherical pellet with $3 \mathrm{~cm}$ in diameter; and

(d) semi-spherical pellet with $2 \mathrm{~cm}$ in diameter.

The spherical pellets with a diameter of $1 \mathrm{~cm}, 2 \mathrm{~cm}$ and $3 \mathrm{~cm}$ were molded manually, using a template with the dimensions printed on a sheet of paper as support, as shown in Figure 2a. For the molding of the semispherical pellets of $2 \mathrm{~cm}$ in diameter, PLA (polylactic acid) filament molds manufactured in a $3 \mathrm{D}$ printer were used (Figure 2b).

The pellets were dried in a kiln at $100 \pm 5{ }^{\circ} \mathrm{C}$ and placed in alumina crucibles, and taken for calcination at $1450^{\circ} \mathrm{C}$ in a laboratory kiln model LHT $02 / 17 \mathrm{LB}$, from the Nabertherm brand. Because of a motorized lifting table, clinkers are automatically exposed to sudden, forced cooling. This step is essential to maintain the mineralogical phases and guarantee the desired properties in the experimental clinker (WINTER, 2012).

The calcination routine of the clinker pellets is shown in Figure 3. The pellets were subjected to a heating rate of $5{ }^{\circ} \mathrm{C} / \mathrm{min}$, until reaching the temperature of $900{ }^{\circ} \mathrm{C}$, remaining at this temperature for 30 minutes for the lime decarbonation. Continuing the second firing stage, with the same heating rate, the samples remained in the kiln until reaching the final temperature of $1450{ }^{\circ} \mathrm{C}$, remaining at that level for 15 minutes before being cooling.

In this research, 12 clinkers were produced, using 3 dosages (reference clinkers, clinkers with CCW-1 and clinkers with $\mathrm{CCW}_{20-40}$ ), and 4 pellets geometries (spherical pellets with diameter of $1 \mathrm{~cm}, 2 \mathrm{~cm}$ and $3 \mathrm{~cm}$; and semi-spherical pellets with diameter of $2 \mathrm{~cm}$ ). Each type of clinker was produced in triplicate and measurements of diameters and masses were carried out. 


\section{Clinker evaluation}

The experimental clinkers were evaluated for mineralogical composition (XRD), using the same diffractometer and conditions used in the characterization of raw materials, except for the amplitude of the diffraction spectra that, for clinkers, were obtained in the range of $2 \theta$ of $5^{\circ}$ at $70^{\circ}$. The crystalline phases present in the clinkers were quantified with the TOPAS Academic software version 4.2, which is based on the Rietveld method and the CIF system (Crystallography Information File). Table 2 presents the crystallographic files used for the quantification of phases by the Rietveld method, also adopted by Mariani et al. (2019).

Figure 2 - Pellets molded (a) manually and (b) in a lactic polyacid mold

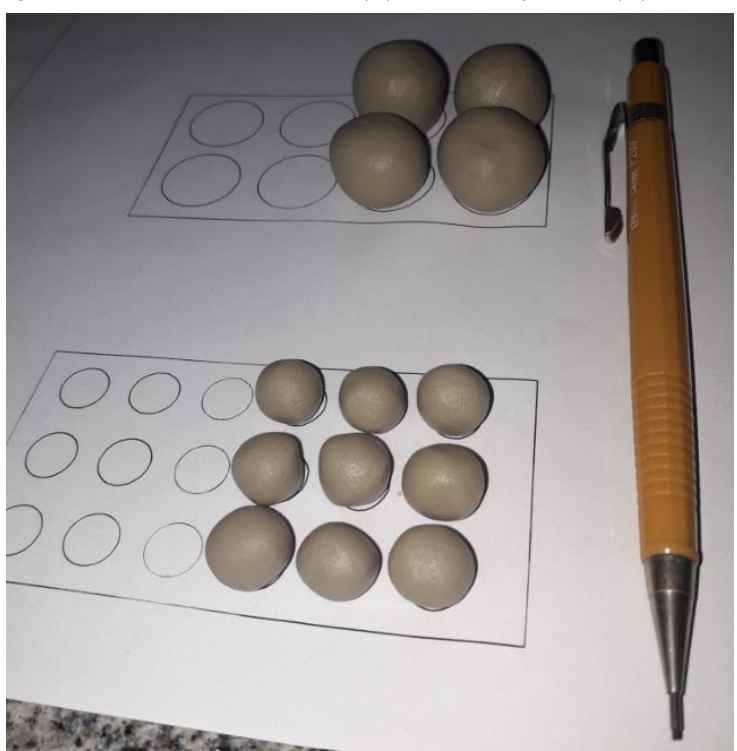

(a)

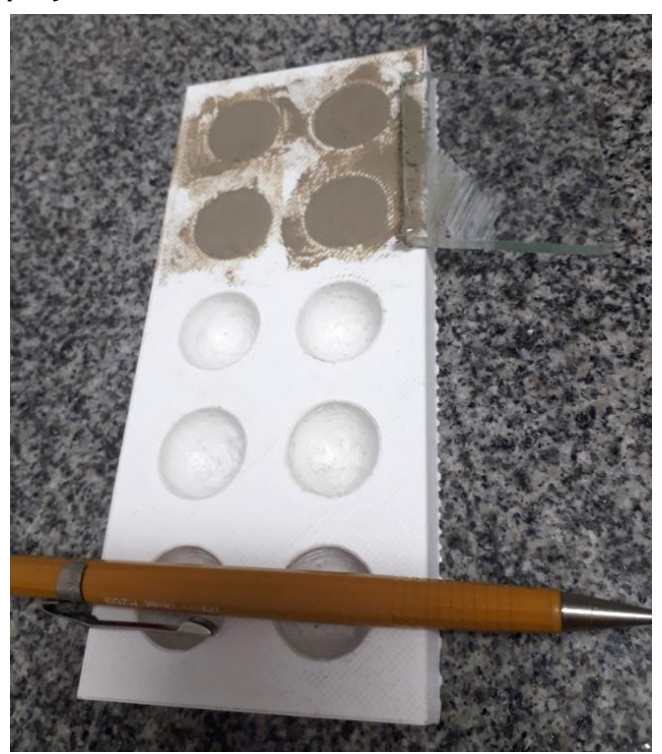

(b)

Figure 3 - Clinkering cycle of pellet samples with LHT 02/17 LB kiln at a maximum temperature of 1450 ${ }^{\circ} \mathrm{C}$

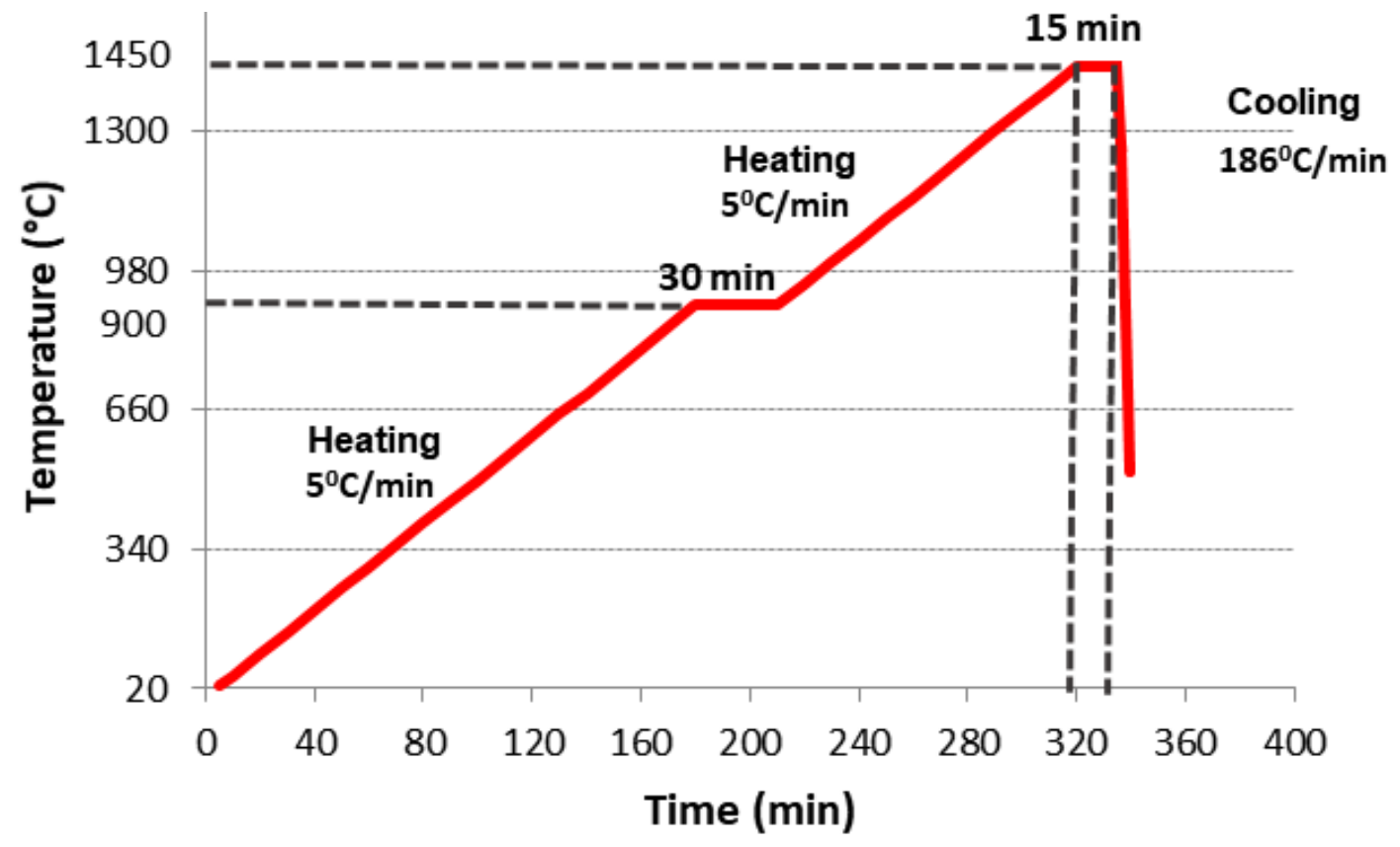

Portland clinker with civil construction waste: influence of pellet geometry on the formation of crystalline 
Table 2 - Crystallographic files used to quantify phases using the Rietveld method

\begin{tabular}{c|c|c|c}
\hline Phase & Crystalline system & ICSD Code & Reference \\
\hline Alite & Monoclinic & 64,759 & Nishi, Takeuchi and Maki (1985) \\
Belite & Monoclinic & 963 & Jost, Ziemer and Seybel (1977) \\
C $_{3}$ A cubic & Cubic & 1,841 & Mondal and Jeffrery (1975) \\
$\mathrm{C}_{3}$ A orthorhombic & Orthorhombic & 1,880 & Nishi and Takeuchi (1975) \\
C $_{4} \mathrm{AF}$ & Orthorhombic & 9,197 & Couville and Geller (1971) \\
Free lime & Cubic & 28,905 & Primak, Kaufman and Ward (1948) \\
Periclase & Cubic & 64,928 & Broch (1927) \\
\hline
\end{tabular}

\section{Results and discussion}

\section{Physical characterization of raw materials}

The values of density and specific surface area BET of the CCW, clay and limestone samples are shown in Table 3. It can be seen that the clay has a specific surface area BET higher than that of the wastes, however, the two CCW samples have a surface area greater than limestone, which can be beneficial at the time of clinker. This parameter indicates the fineness or a higher surface roughness of the material, which is directly proportional to the reactivity (GOMES et al., 2019). In addition, all the materials used have a high surface area and small $\mathrm{D}_{50}$ values, which shows the efficiency of the grinding process. This is so that problems such as low reactivity and formation of agglomerates of belite and free lime will probably not occur (PUERTAS et al., 2008).

The particle size distributions of the limestone, clay and CCW samples, obtained by laser granulometry, are shown in Figure 4. From the analysis of the granulometric distribution curves, it can be seen that the grains of both benefited samples from the $\mathrm{CCW}$ and the limestone and clay have an average diameter $\left(\mathrm{D}_{50}\right)$ below $75 \mu \mathrm{m}$, as expected, which is important to facilitate the adequate reaction of these materials during the clinker process to produce Portland cement (PUERTAS et al., 2008).

\section{Chemical characterization of raw materials}

The chemical compositions of the CCW, besides clay and limestone, the materials traditionally used in the manufacture of Portland cement, were obtained by x-ray fluorescence (XRF), in the form of oxides, and losses on ignition, and the results are shown in Table 4. It is said that construction waste is rich in silicon, calcium, aluminum, and iron, besides other elements in a smaller proportion, such as magnesium, sulfur, sodium, potassium, and titanium.

$\mathrm{CCW}$ is a source of calcium oxide, containing 17.5 to $26.7 \%$ of $\mathrm{CaO}$, and is used as an alternative raw material to limestone, traditionally used in flour, to produce clinker. This calcium oxide present in the CCW is an environmentally adequate source of calcium, without needing decarbonation process and consequent $\mathrm{CO}_{2}$ generation, such as occurs with limestone, responsible for the high loss on ignition (LOI about $37.5 \%$ to sample used). Limestone decarbonation (calcite decomposition) occurs at an approximate temperature of $900{ }^{\circ} \mathrm{C}$, generating $\mathrm{CO}_{2}$ as a by-product $\left(\mathrm{CaCO}_{3} \rightarrow \mathrm{CaO}+\mathrm{CO}_{2}\right)$. For each $1,000 \mathrm{~kg}$ of calcined calcite, 560 $\mathrm{kg}$ of $\mathrm{CaO}$ and $440 \mathrm{~kg}$ of $\mathrm{CO}_{2}$ are generated. Thus, the loss on ignition from high-purity limestone can reach 44\% (BRANDŠTETR; HAVLICA; ODLER, 1997; ALI; SAIDUR; HOSSAIN, 2011).

$\mathrm{CCW}$ samples can also be used as a source of silica alternative to clay, as they have 28.8 to $42.4 \% \mathrm{SiO}_{2}$. Thus, it is clear that this CCW is an important alternative source of calcium and silicon, and can replace part of the clay-limestone system, traditional raw materials used in the production of Portland cement.

$\mathrm{CCW}$ present about $2.8 \% \mathrm{SO}_{3}$, a value ten times higher than that found in clay and limestone, added together. The effect of smaller components on clinker formation has been studied and cited as beneficial due to the ability of some of them to act as mineralizing agents (KOLOVOS et al., 2001; MARIANI et al., 2019). These components, such as fluorine, sulfur and titanium, can decrease the temperature of the first formation of the liquid phase and / or speed up the rate of reactions that occur in the solid state, in the liquid phase or in the liquid-solid interface (mineralizers), changing the viscosity and surface tension of the molten material and affecting crystal growth and morphology. The technological consequences are clear: changes in the reactivity and burning capacity of raw materials, formation of new phases in altered quantities, differentiation of hydraulic activity and the properties of the cements produced, opportunities for energy

212 Costa, F. N.; Ribeiro, D. V.; Dias, C. M. R. 
conservation. However, there are limitations because of the restrictions related to the $\mathrm{SO}_{3}$ content in cement and its volatility, which can cause it to accumulate in the ovens and preheaters in the cement factories.

\section{Mineralogical characterization of raw materials}

Figure 5 shows the $\mathrm{x}$-ray diffractograms of the $\mathrm{CCW}$ samples used. It is observed that clay is the main source of kaolinite $\left[\mathrm{Si}_{2} \mathrm{Al}_{2} \mathrm{O}_{5}(\mathrm{OH})_{4}\right]$, quartz $\left(\mathrm{SiO}_{2}\right)$, and muscovite $\left(\mathrm{Al}_{3} \mathrm{KSi}_{3} \mathrm{O}_{12}\right)$ and limestone, source of calcite $\left(\mathrm{CaCO}_{3}\right)$, dolomite $\left[\mathrm{CaMg}\left(\mathrm{CO}_{3}\right)_{2}\right]$, and quartz $\left(\mathrm{SiO}_{2}\right)$.

The quantitative assessment of the phases showed that the largest source of silica is clay, $(42.5 \%$, ) with limestone comprising only $4 \%$ silica. Limestone is the main source of calcium, making up the mineral calcite, with approximately $92 \%$, as expected and according to the results of the chemical composition, shown in Table 4.

In relation to the $\mathrm{CCW}$, the various existing crystalline phases show its heterogeneous character, composed of hydrated cementitious materials (mortars and concrete), ceramic, and concrete blocks, ceramic tiles and tiles, clay minerals of soils, ornamental rocks (granites and marbles), aggregates, among other materials. The $\mathrm{CCW}$ used is composed mainly of quartz $\left(\mathrm{SiO}_{2}\right)$, calcite $\left(\mathrm{CaCO}_{3}\right)$, microcline $\left(\mathrm{KAlSi}_{3} \mathrm{O}_{8}\right)$, and muscovite $\left(\mathrm{Al}_{3} \mathrm{KSi}_{3} \mathrm{O}_{12}\right)$ in greater proportions, besides the minority presence of the dolomite phases $\left[\mathrm{CaMg}\left(\mathrm{CO}_{3}\right)_{2}\right]$, anitte $\left[\mathrm{KFe}_{3} \mathrm{AlSi}_{3} \mathrm{O}_{10}(\mathrm{OH})_{2}\right]$, estantite $\left(\mathrm{MgSiO}_{3}\right)$, ferrosilite $\left(\mathrm{FeSiO}_{3}\right)$, and gypsum $\left[\mathrm{Ca}\left(\mathrm{SO}_{4}\right) \cdot 2 \mathrm{H}_{2} \mathrm{O}\right]$.

\section{Dosing and production of Portland clinkers containing CCW}

Table 5 shows the percentages of each raw material used for the manufacturing of the experimental clinkers with incorporating CCW and reference clinker (produced with limestone and clay). It is observed that it was possible to completely replace the clay with $\mathrm{CCW}$, incorporating approximately 9.5 to $14.3 \%$ of $\mathrm{CCW}$ into the mixture in the raw flour (raw mix).

Table 3 - Density, specific surface area BET and $\mathrm{D}_{50}$ of CCW, clay and limestone

\begin{tabular}{c|c|c|c}
\hline Materials & Density $\left(\mathbf{K g} / \mathbf{m}^{\mathbf{3}}\right)$ & Specific Surface Area BET $\left(\mathbf{m}^{2} / \mathbf{g}\right)$ & D $50(\boldsymbol{\mu} \mathbf{m})$ \\
\hline $\mathrm{CCW}-1$ & $2.4691 \pm 0.0041$ & 16.7010 & 49 \\
$\mathrm{CCW}_{20-40}$ & $2.6342 \pm 0.0040$ & 13.6570 & 20 \\
Clay & $2.6985 \pm 0.0020$ & 30.1725 & 10 \\
Limestone & $2.7255 \pm 0.0014$ & 5.8454 & 2.9 \\
\hline
\end{tabular}

Figure 4 - Particle size distribution of limestone, clay, CCW-1 and CCW $20-40$, obtained by laser granulometry

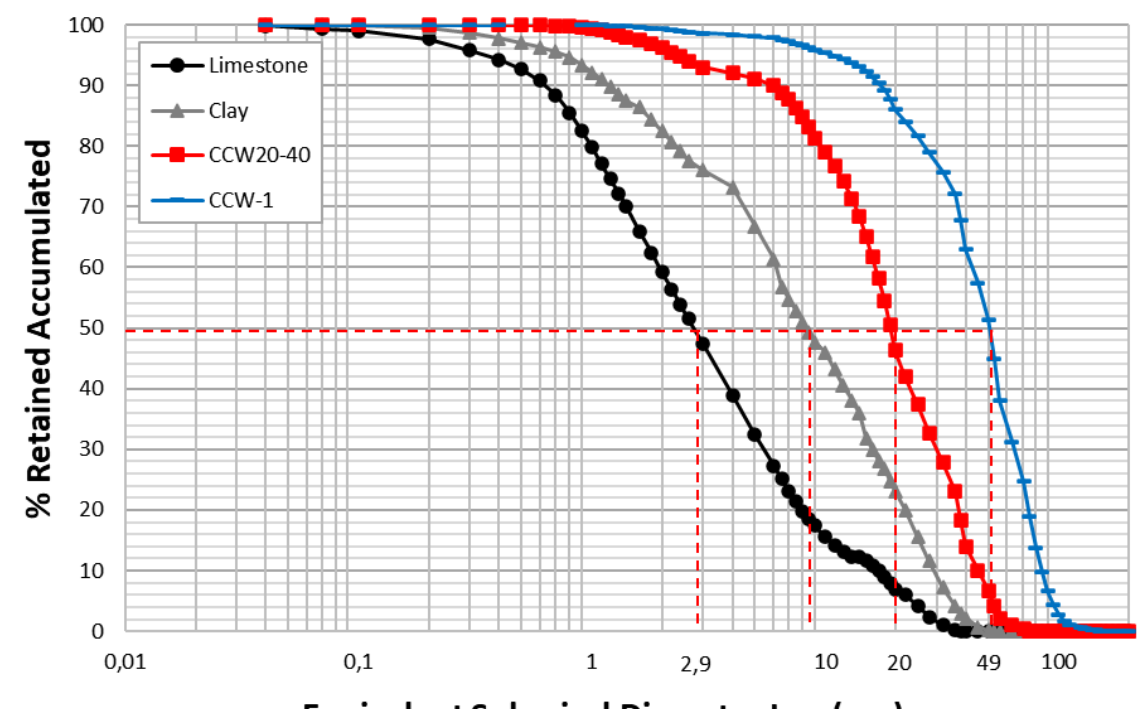

Equivalent Spherical Diameter Log $(\mu \mathrm{m})$ 
Table 4 - Chemical characterization, in oxides, obtained by means of XRF, for CCW, limestone, and clay

\begin{tabular}{c|c|c|c|c|c|c|c|c|c|c|c}
\hline Materials & $\mathbf{S i O}_{2}$ & $\mathbf{C a O}$ & $\mathbf{A l}_{2} \mathbf{O}_{3}$ & $\mathbf{F e}_{2} \mathbf{O}_{3}$ & $\mathbf{M g O}$ & $\mathbf{S O}_{3}$ & $\mathbf{N a}_{2} \mathbf{O}$ & $\mathbf{K}_{2} \mathbf{O}$ & $\mathbf{T i O}_{2}$ & Others & $\mathbf{L O I} *$ \\
\hline $\mathrm{CCW}-1$ & 28.82 & 26.73 & 7.50 & 3.21 & 3.38 & 1.74 & 1.65 & 1.40 & 0.55 & 0.23 & 24.80 \\
$\mathrm{CCW}_{20-40}$ & 42.45 & 17.50 & 11.67 & 4.03 & 3.44 & 2.82 & 1.98 & 0.86 & 0.60 & 0.75 & 13.90 \\
Clay & 58.42 & 0.26 & 23.55 & 4.79 & 1.18 & 0.12 & - & 1.39 & 1.10 & 0.35 & 8.85 \\
Limestone & 10.92 & 44.04 & 3.20 & 1.28 & 2.13 & 0.10 & - & 0.58 & 0.18 & 0.08 & 37.50 \\
\hline
\end{tabular}

Nota: *LOI: loss on ignition at $1000{ }^{\circ} \mathrm{C}$.

Figure 5 - Diffractograms of (a) clay, (b) limestone, (c) CCW $20-40$, and (d) CCW-1

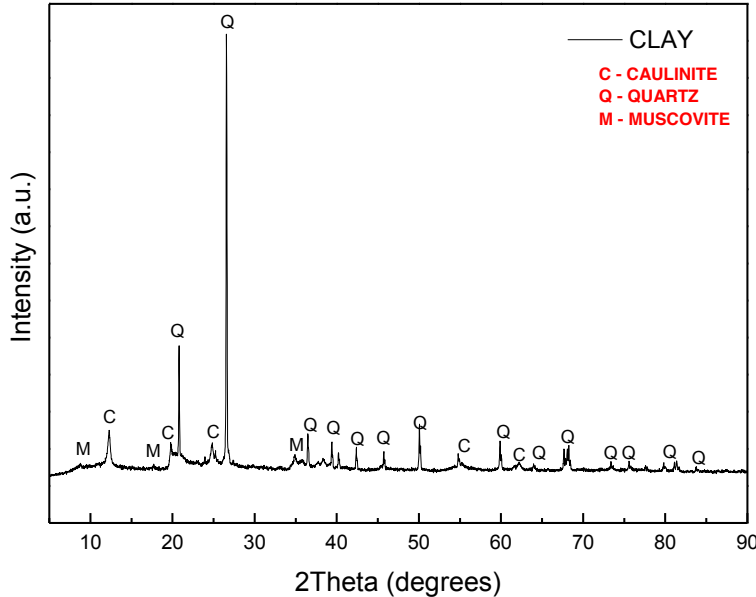

(a)

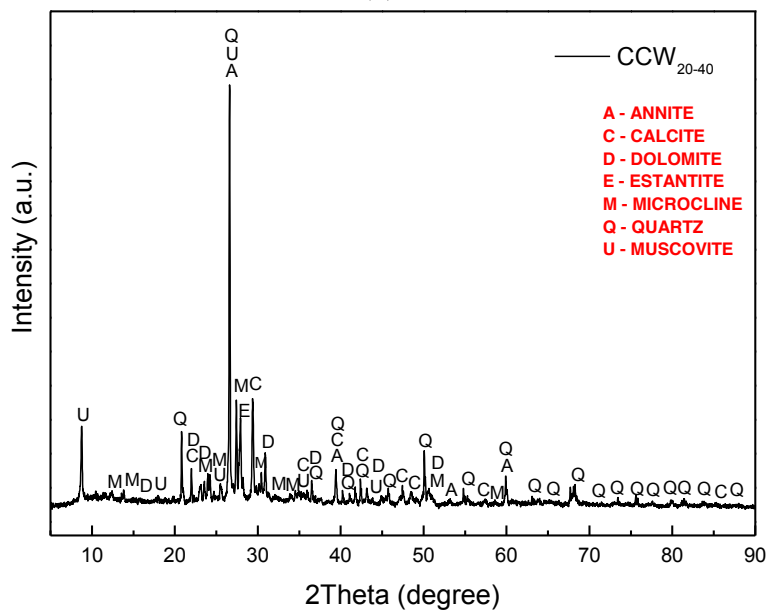

(c)

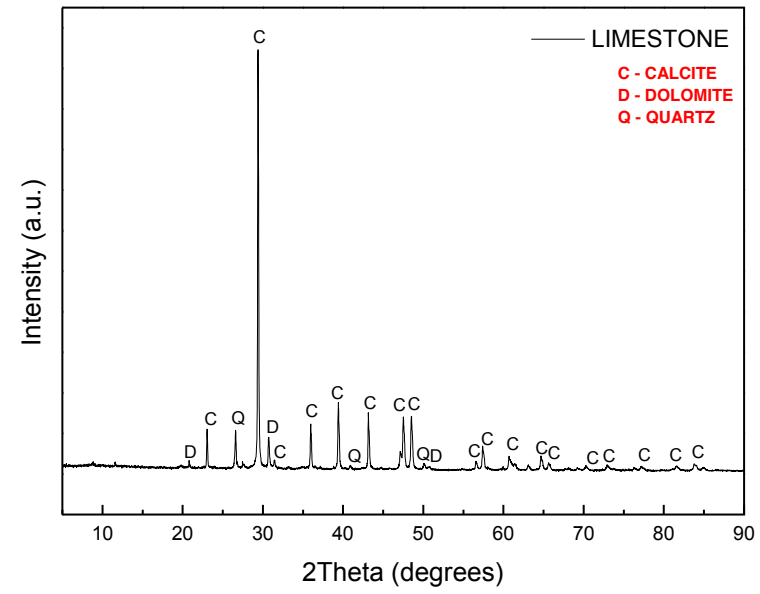

(b)

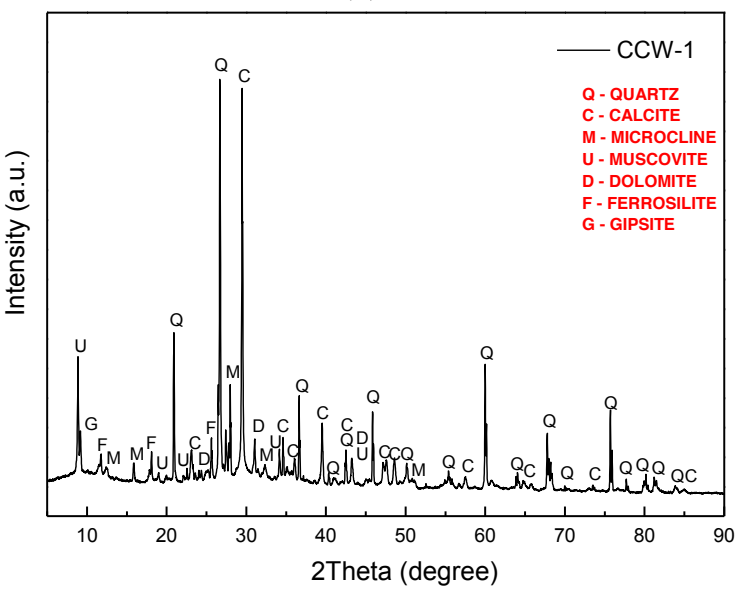

(d)

Table 5 - Percentage, by mass, of each raw material, in the composition of precursor raw mix to produce experimental clinkers, with LSF set at $98 \%$ and resulting chemical parameters

\begin{tabular}{|c|c|c|c|c|c|c|}
\hline \multirow{2}{*}{ Clinker } & \multicolumn{3}{|c|}{ Materials $(\%)$} & \multicolumn{3}{|c|}{ Chemical parameters } \\
\hline & Limestone & Clay & CCW & LSF (\%) & $\mathbf{S M}$ & $\mathbf{A M}$ \\
\hline F-REFERENCE & 93.20 & 6.80 & - & 98 & 2.35 & 2.88 \\
\hline F-CCW-1 & 85.71 & - & 14.29 & 98 & 2.36 & 2.63 \\
\hline $\mathrm{F}-\mathrm{CCW} 20-40$ & 90.50 & - & 9.50 & 98 & 2.47 & 2.52 \\
\hline
\end{tabular}

As the $\mathrm{CCW}$ is an alternative source of the main chemical elements of the clinker $\left(\mathrm{CaO}, \mathrm{SiO}_{2}, \mathrm{Al}_{2} \mathrm{O}_{3}\right.$, and $\mathrm{Fe}_{2} \mathrm{O}_{3}$ ), being a rich and important source of $\mathrm{CaO}$, incorporating $\mathrm{CCW}$ enabled the reduction of about 3 to 8 $\%$ of limestone in the raw mix. Thus, it is possible to reduce or dispense with the need for clay extraction, 
incorporating the $\mathrm{CCW}$ into the clinkering process, reincorporating this waste into the production chain and offering an adequate and sustainable final destination alternative. In addition, the use of CCW implies less environmental impact, by decreasing the emission of carbon dioxide $\left(\mathrm{CO}_{2}\right)$. However, since the $\mathrm{CCW}$ is heterogeneous, the content of incorporation of the waste in the raw mix may be higher, depending on its chemical constitution.

Besides the environmental benefits, incorporating $\mathrm{CCW}$ brings benefits to the clinkering process. Kolovos et al. (2001) researched the effect of smaller elements of the raw mix in the $\mathrm{CaO}-\mathrm{SiO}_{2}-\mathrm{Al}_{2} \mathrm{O}_{3}-\mathrm{Fe}_{2} \mathrm{O}_{3}$ system and found that sulfur-containing compounds improve the reactivity of the mixture and speed up the $\mathrm{CaO}$ combination, especially during the final clinker stage. Another study developed by Raina and Janakiraman (1998) concluded that $\mathrm{SO}_{3}$ speeds up the decomposition of $\mathrm{CaCO}_{3}$ at a lower temperature, thus reducing heat consumption or fuel intake. The growth of $\mathrm{C}_{3} \mathrm{~S}$ crystals is also favored to form a liquid phase at a lower temperature. $\mathrm{SO}_{3}$ can stabilize $\mathrm{C}_{3} \mathrm{~S}$, preventing it from becoming $\mathrm{C}_{2} \mathrm{~S}$ and favoring the development of resistance in cements.

In the dosage incorporating the $\mathrm{CCW}$ in question, the amount of sulfur present in the waste is within the amount considered adequate for incorporation into the raw mix. The maximum content of incorporated $\mathrm{CCW}$ was $9.5 \%$, which represents a content of $0.27 \% \mathrm{SO}_{3}$, considering the chemical composition of the CCW shown in Table 4.

In Brazil, NBR 16697 (ABNT, 2018) establishes that the content of $\mathrm{SO}_{3}$ (\% by mass), from clinker in soluble and insoluble form and calcium sulfate (gypsum) added to cement, must be less than $4.5 \%$ for all types of Portland cement.

\section{Evaluation of Portland clinkers in four different molding configurations}

Clinkers in the three different pellet configurations were evaluated for mineralogical composition in order to verify the formation of the expected crystalline phases. The diffractograms of the reference clinkers, produced with limestone and clay, and of clinkers with CCW incorporation are shown in Figures 6, 7 and 8.

Figure 6 - Diffractograms of reference clinkers (without CCW) produced in spherical pellets of (a) $1 \mathrm{~cm}$, (b) $2 \mathrm{~cm}$ and (c) $3 \mathrm{~cm}$ and, (d) semi-spherical with $2 \mathrm{~cm}$ in diameter

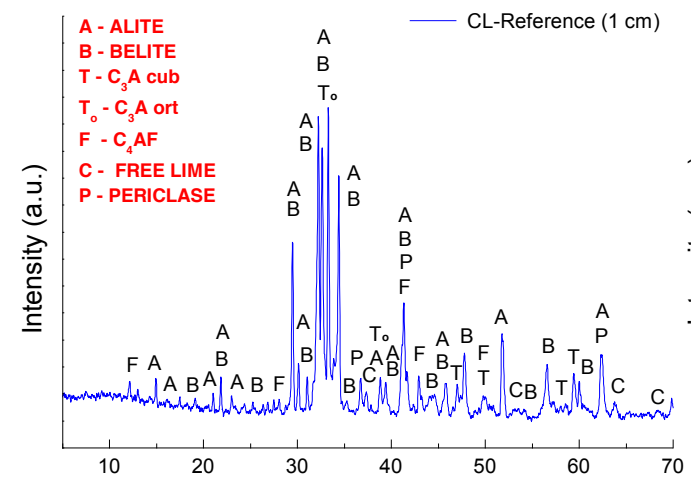

(a)

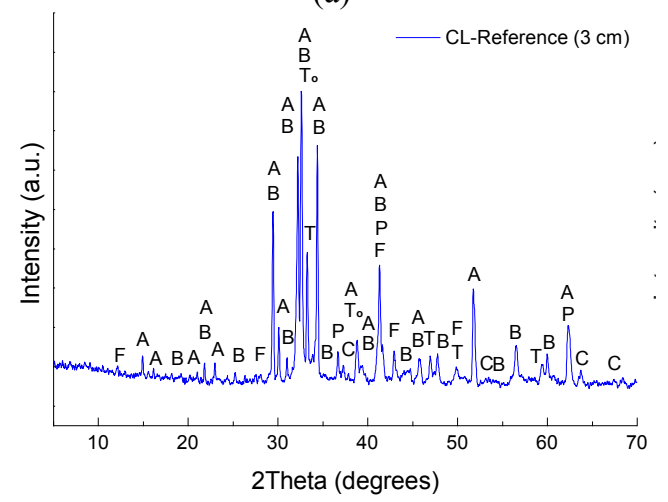

(c)

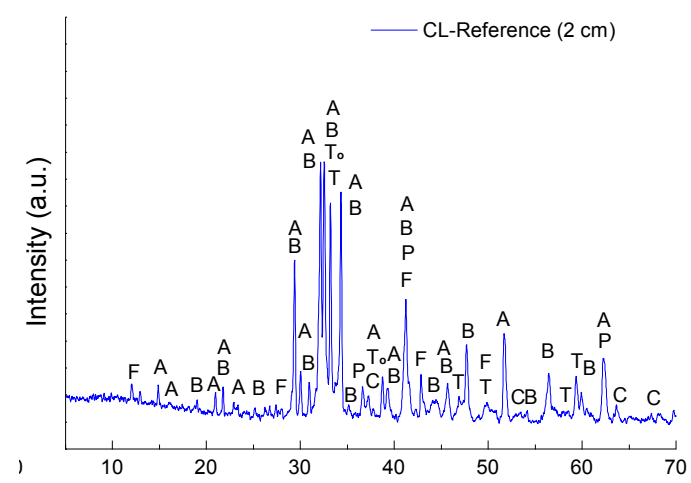

(b)

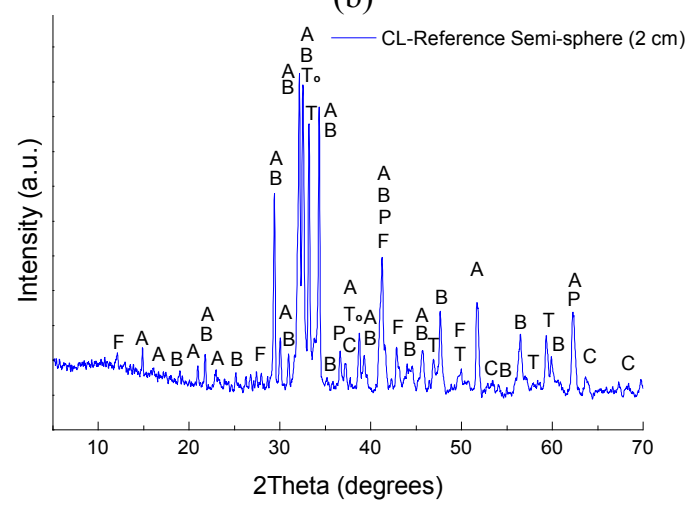

(d) 
Figure 7 - Diffractograms of clinkers with $\mathrm{CCW}_{20-40}$ incorporation produced in spherical pellets of (a) 1 $\mathrm{cm}$, (b) $2 \mathrm{~cm}$ and (c) $3 \mathrm{~cm}$ and, (d) semi-spherical with $2 \mathrm{~cm}$ in diameter

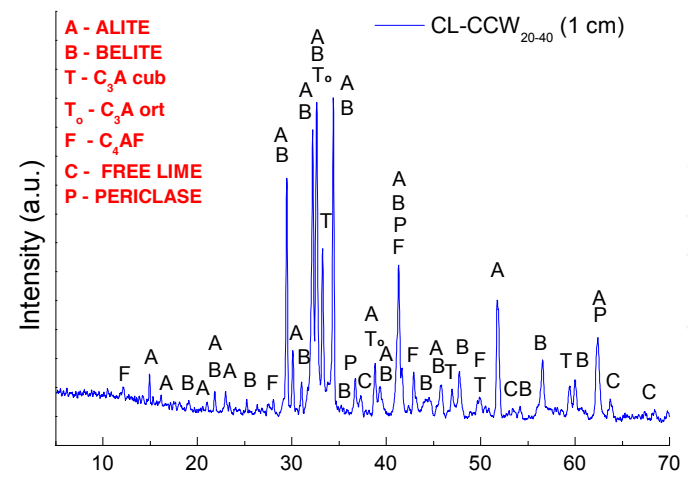

(a)

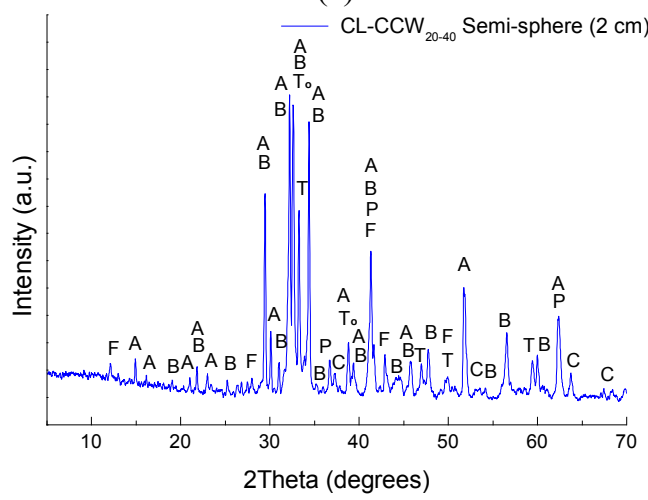

(c)

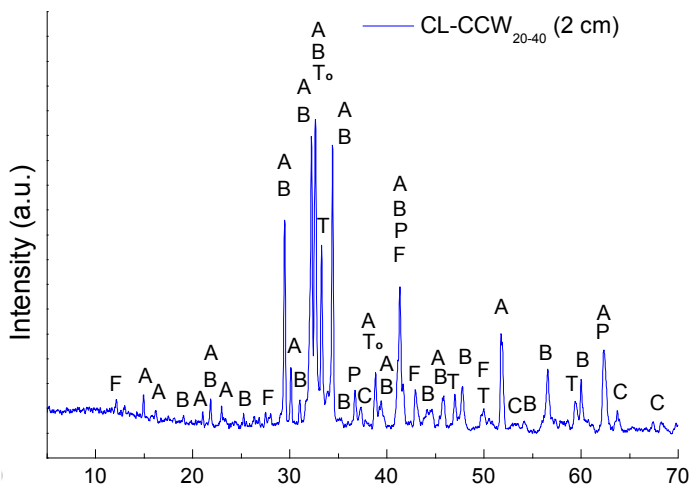

(b)

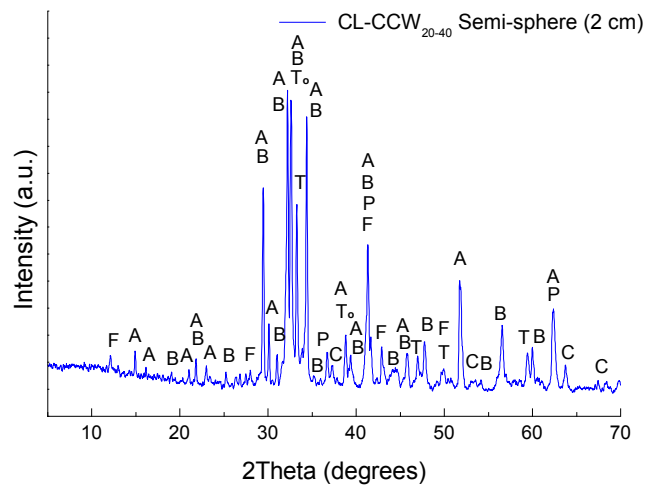

(d)

Figure 8 - Diffractograms of clinkers with CCW-1 incorporation produced with spherical pellets of (A) 1 $\mathrm{cm}$, (B) $2 \mathrm{~cm}$ and (C) $3 \mathrm{~cm}$ and, (D) semi-spherical with $2 \mathrm{~cm}$ in diameter

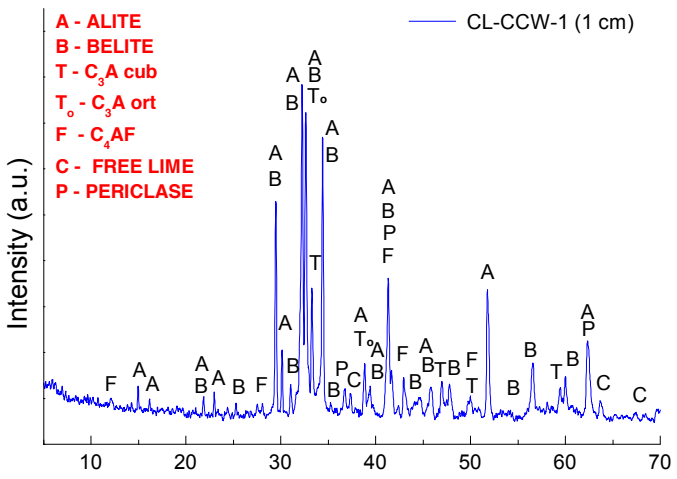

(a)

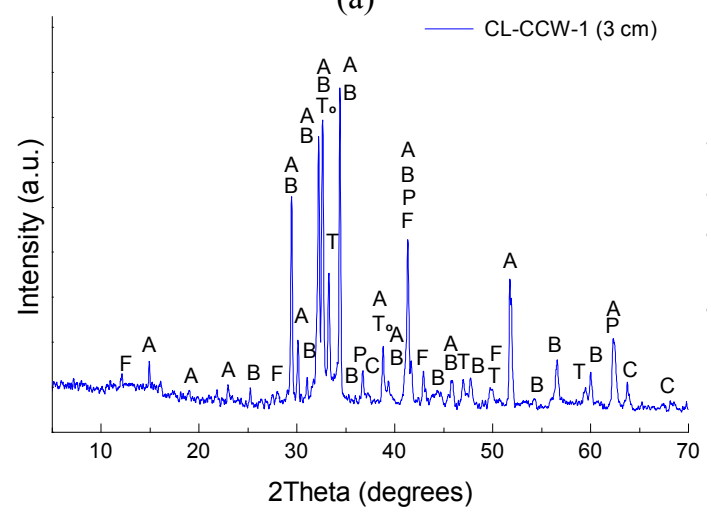

(c)

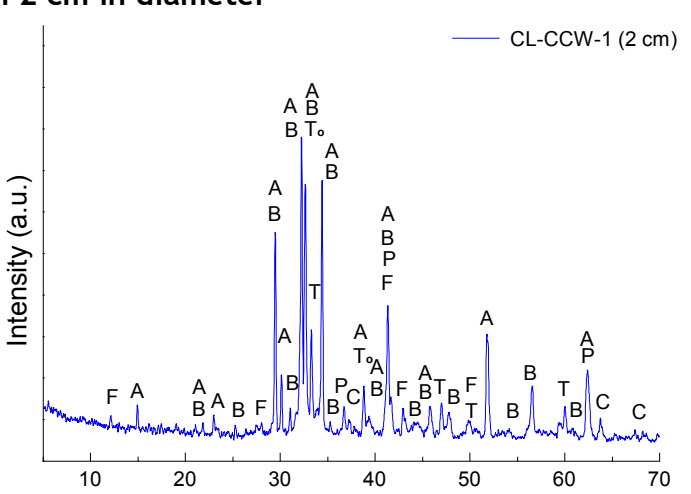

(b)

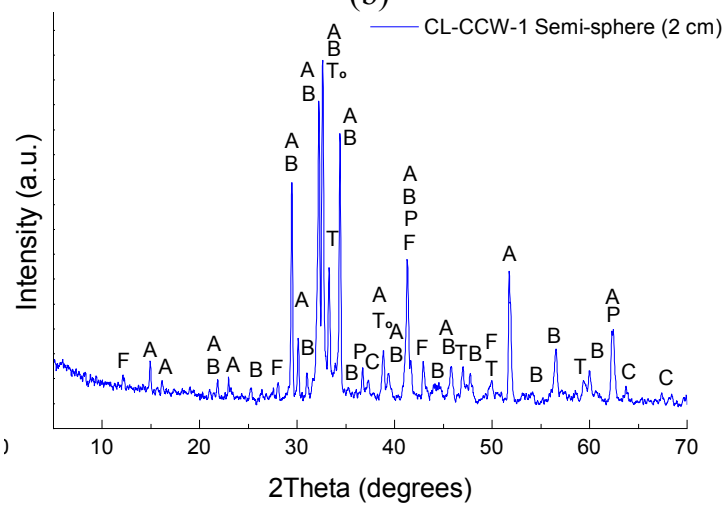

(d)

216 Costa, F. N.; Ribeiro, D. V.; Dias, C. M. R. 
It can be observed that all the clinkers produced with the four different pellet configurations presented the expected crystalline phases, mainly of alite and belite, phases that should be the majority. Regardless of the pellet configuration, the minor clinker phases, $\mathrm{C}_{3} \mathrm{~A}$ and $\mathrm{C}_{4} \mathrm{AF}$, were also formed, as can be seen in the diffractograms.

The mineralogical results show that all the clinkers produced with the three different pellet configurations presented the expected crystalline phases, mainly of alite and belite, must be majority. Regardless of the pellet configuration, the minor clinker phases, $\mathrm{C}_{3} \mathrm{~A}$ and $\mathrm{C}_{4} \mathrm{AF}$, were also formed, as can be seen in the diffractograms. The quantification of the identified phases is shown in Tables 6 and 7 .

Table 6 - Crystalline phase contents of the experimental reference clinkers (CL, without CCW), calcined at $1450{ }^{\circ} \mathrm{C}$, obtained using the Rietveld method

\begin{tabular}{c|c|c|c|c}
\hline \multirow{2}{*}{$\begin{array}{c}\text { Clinker } \\
\text { Phases }\end{array}$} & $\begin{array}{c}\text { CL-Reference } \\
(\mathbf{1} \mathbf{~ c m})\end{array}$ & $\begin{array}{c}\text { CL-Reference } \\
(\mathbf{2} \mathbf{~ c m})\end{array}$ & $\begin{array}{c}\text { CL-Reference } \\
(\mathbf{3} \text { cm })\end{array}$ & $\begin{array}{c}\text { CL-Reference } \\
\text { Semi-sphere (2 cm) }\end{array}$ \\
\cline { 2 - 5 } & \multicolumn{4}{|c}{ Average contents (\%) } \\
\hline Alite & $59.0 \pm 0.39$ & $55.1 \pm 0.92$ & $54.7 \pm 1.01$ & $57.6 \pm 0.40$ \\
Belite & $24.0 \pm 0.50$ & $27.3 \pm 1.76$ & $29.1 \pm 0.76$ & $25.1 \pm 1.18$ \\
C $_{3}$ A cubic & $9.9 \pm 0.93$ & $10.1 \pm 0.45$ & $9.5 \pm 0.66$ & $10.3 \pm 0.26$ \\
$\mathrm{C}_{3}$ A orthorhombic & $1.0 \pm 0.22$ & $1.5 \pm 0.34$ & $1.2 \pm 0.26$ & $1.5 \pm 0.82$ \\
C 4 AF & $3.3 \pm 0.47$ & $3.5 \pm 0.61$ & $3.0 \pm 0.39$ & $3.0 \pm 0.04$ \\
Free lime & $0.3 \pm 0.17$ & $0.1 \pm 0.06$ & $0.2 \pm 0.03$ & $0.2 \pm 0.13$ \\
Periclase & $2.5 \pm 0.09$ & $2.4 \pm 0.33$ & $2.3 \pm 0.25$ & $2.3 \pm 0.53$ \\
GOF* & $1.18 \pm 0.07$ & $1.15 \pm 0.03$ & $1.22 \pm 0.06$ & $1.18 \pm 0.09$ \\
\hline
\end{tabular}

Note: *statistical indicator that provides the relationship between expected and calculated residues: GOF (goodness of fit) = RwP (weighted profile $R$ factor) / $R_{\exp }$ (expected $R$ factor).

Table 7 - Crystalline phase contents of experimental clinkers with the incorporation of CCW (CL-CCW 20 40 and $\mathrm{CL}-\mathrm{CCW}-1)$, calcined at $1450^{\circ} \mathrm{C}$, obtained using the Rietveld method

\begin{tabular}{|c|c|c|c|c|}
\hline \multirow{2}{*}{$\begin{array}{l}\text { Clinker } \\
\text { Phases }\end{array}$} & $\begin{array}{l}\text { CL-CCW20-40 } \\
(1 \mathrm{~cm})\end{array}$ & $\begin{array}{l}\text { CL-CCW } 20-40 \\
(2 \mathrm{~cm})\end{array}$ & $\begin{array}{l}\text { CL-CCW } 20-40 \\
(3 \mathrm{~cm})\end{array}$ & $\begin{array}{c}\text { CL-CCW } 20-40 \\
\text { Semi-sphere }(2 \mathrm{~cm})\end{array}$ \\
\hline & \multicolumn{4}{|c|}{ Average contents (\%) } \\
\hline Alite & $60.8(1.06)$ & $56.7(0.54)$ & $58.0(1.08)$ & $59.1(1.40)$ \\
\hline Belite & $25.5(0.56)$ & $29.0(0.32)$ & $27.0(0.85)$ & $25.8(0.79)$ \\
\hline $\mathrm{C}_{3} \mathrm{~A}$ cubic & $6.7(0.21)$ & $7.2(1.25)$ & $7.5(0.65)$ & $7.2(1.06)$ \\
\hline $\mathrm{C}_{3} \mathrm{~A}$ orthorhombic & $0.7(0.22)$ & $1.3(0.51)$ & $1.3(0.52)$ & $1.6(1.17)$ \\
\hline $\mathrm{C}_{4} \mathrm{AF}$ & $3.5(1.75)$ & $3.3(1.26)$ & $3.2(1.22)$ & $3.3(1.29)$ \\
\hline Free lime & $0.3(0.17)$ & $0.2(0.12)$ & $0.3(0.21)$ & $0.3(0.35)$ \\
\hline Periclase & $2.5(0.32)$ & $2.3(0.36)$ & $2.6(0.24)$ & $2.7(0.25)$ \\
\hline GOF* & $1.14(0.02)$ & $1.19(0.02)$ & $1.19(0.04)$ & $1.14(0.02)$ \\
\hline \multirow{2}{*}{$\begin{array}{l}\text { Clinker } \\
\text { Phases }\end{array}$} & $\begin{array}{c}\text { CL-CCW-1 } \\
(1 \mathrm{~cm})\end{array}$ & $\begin{array}{c}\text { CL-CCW-1 } \\
(2 \mathrm{~cm})\end{array}$ & $\begin{array}{c}\text { CL-CCW-1 } \\
(3 \mathrm{~cm})\end{array}$ & $\begin{array}{c}\text { CL-CCW-1 } \\
\text { Semi-sphere }(2 \mathrm{~cm})\end{array}$ \\
\hline & \multicolumn{4}{|c|}{ Average contents (\%) } \\
\hline Alite & $60.5(1.27)$ & $56.5(1.87)$ & $56.2(1.08)$ & $57.2(1.29)$ \\
\hline Belite & $22.8(1.46)$ & $24.7(1.29)$ & $27.6(1.13)$ & $24.0(0.41)$ \\
\hline $\mathrm{C}_{3} \mathrm{~A}$ cubic & $9.3(0.36)$ & $10.0(0.80)$ & $9.4(0.88)$ & $11.6(0.21)$ \\
\hline $\mathrm{C}_{3} \mathrm{~A}$ orthorhombic & $1.5(0.65)$ & $1.6(1.20)$ & $1.1(0.48)$ & $0.9(0.13)$ \\
\hline $\mathrm{C}_{4} \mathrm{AF}$ & $3.0(0.07)$ & $3.9(0.75)$ & $3.1(0.53)$ & $3.3(0.83)$ \\
\hline Free lime & $0.0(0.06)$ & $0.4(0.12)$ & $0.3(0.13)$ & $0.3(0.24)$ \\
\hline Periclase & $2.8(0.24)$ & $2.8(0.18)$ & $2.3(1.04)$ & $2.7(0.22)$ \\
\hline GOF* & $1.21(0.02)$ & $1.20(0.03)$ & $1.23(0.06)$ & $1.22(0.01)$ \\
\hline
\end{tabular}

Note: *statistical indicator that provides the relationship between expected and calculated residues: GOF (goodness of fit) = Rwp (weighted profile R factor) / Rexp (expected R factor). 
From the quantification results of the formed phases, it appears that the alite phase was formed in greater quantity in all clinkers, regardless of the pellet configurations and the presence of the $\mathrm{CCW}$, indicating that the wastes adequately replaced part of the limestone-clay system. For the production of Portland cement, the alite phase must be the major constituent of clinker, because among the other phases, this is the one that has the greatest influence on the hardening of cement, being responsible for the development of mechanical strengths in the early ages (YOUNG; YANG, 2019). In a research using granite rocks fines, waste generated in the production process of aggregates for civil construction to produce clinker, similar promising results were found, resulting in higher amounts of alite when compared to the reference clinker, when incorporating 1.2 to $5.5 \%$ of the waste (GOMES et al., 2019).

Among the four pellet configurations used, clinkers with spheres of $1 \mathrm{~cm}$ in diameter were the ones that had the highest content of alite, both in reference clinkers and in clinkers with $\mathrm{CCW}$. The clinkers produced with semi-spherical pellets with a diameter of $2 \mathrm{~cm}$, presented intermediate contents of alite and, as expected, the clinkers produced with spheres of $3 \mathrm{~cm}$ in diameter were the ones that formed the lowest contents of alite. In industry, the raw mix is burned in a rotating kiln, with the powder gradually being heated inside the kiln by rotating movement (CHATTERJEE, 2011) resulting in nodular material with varying diameters. The formation of nodules (nodulization) occurs through the union of solid particles by liquid and requires an adequate proportion of liquid, favored by the low viscosity and high surface tension of the liquid and the small particle size of the solids. Alite formation and loss of volatiles affect nodulization, and the compaction that the latter entails must affect the kinetics of the former processes. Therefore, alite formation occurs in a changing environment inside the furnace (TAYLOR, 1997). As already reported, in this laboratory research using a static electric kiln, the previously shaped pellets are calcined and the clinker process occurs with each pellet in the previously defined position inside the kiln, that is, nodulation is forced during molding, contrary to what occurs in industrial kiln. The decrease in the size of the pellets increases their surface area and, with the reduction in associated mass, there is a greater energy associated with these pellets, facilitating the formation of alite, which needs more energy to be formed, from the belite. It is known that alite (formed from $1260{ }^{\circ} \mathrm{C}$ ), the main cement phase, is formed from the reaction of belite (formed from $800{ }^{\circ} \mathrm{C}$ ) with $\mathrm{CaO}$ (TAYLOR, 1997). In other words, during clinkering, previously molded pellets with larger dimensions, or smaller specific surface area, require greater energy for the reactions to occur properly, as they do in an industrial rotary kiln. Thus, pellets with a greater specific surface area are more favorable in forming higher alite content.

The results obtained were evaluated statistically by means of analysis of variance (ANOVA), presented in Tables 8, 9 and 10. The analyzes were made by comparing the results of the alite phases in clinkers produced from pellets with $1 \mathrm{~cm}$ in diameter in relation to the other pellet configurations and indicated that the differences in the percentages of alite formed between the different pellet configurations are statistically significant, except for clinkers with CCW-1 incorporation, between $1 \mathrm{~cm}$ pellets and $2 \mathrm{~cm}$ diameter semisphere (Table 10).

Table 8 - Statistical confidence for reference clinkers, produced with $1 \mathrm{~cm}, 2 \mathrm{~cm}, 3 \mathrm{~cm}$ pellets, and 2 $\mathrm{cm}$ diameter semi-sphere, through analysis of variance (ANOVA)

\begin{tabular}{|c|c|c|c|c|c|c|c|}
\hline Pellet type groups & SS & DF & $\mathbf{S A}$ & $\mathbf{F}$ & Value-P & Fc & Significant effect \\
\hline $1 \mathrm{~cm} / 2 \mathrm{~cm}$ & 10.935 & 1 & 10.935 & 8.99 & 0.03998 & 7.71 & YES \\
\hline $1 \mathrm{~cm} / 3 \mathrm{~cm}$ & 27.950 & 1 & 27.950 & 48.08 & 0.0022 & 7.71 & YES \\
\hline $\begin{array}{l}1 \mathrm{~cm} / \text { Semi-sphere } \\
(2 \mathrm{~cm} \text { in diameter })\end{array}$ & 3.226 & 1 & 3.226 & 20.98 & 0.0101 & 7.71 & YES \\
\hline $\begin{array}{l}\mathrm{SS}=\text { Square Sum; } \\
\mathrm{DF}=\text { Degrees of freedom; } \\
\mathrm{SA}=\text { square average; } \\
\mathrm{F}=\text { calculated value of } \mathrm{F} ; \\
\text { Value }-\mathrm{P}=\text { Significance le } \\
\mathrm{FC}=\text { Critical F; and } \\
\text { If } \mathrm{p}<5 \% \text { and } \mathrm{FC}<\mathrm{F} \text {, the ef }\end{array}$ & 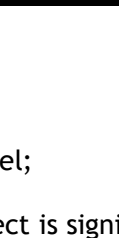 & & & & & & \\
\hline
\end{tabular}

218 Costa, F. N.; Ribeiro, D. V.; Dias, C. M. R. 
Table 9 - Statistical confidence for clinkers with $\mathrm{CCW}_{20-40}$ incorporation, produced with $1 \mathrm{~cm}, 2 \mathrm{~cm}, 3$ $\mathrm{cm}$ pellets, and $2 \mathrm{~cm}$ diameter semi-sphere, through analysis of variance (ANOVA)

\begin{tabular}{l|c|c|c|c|c|c|c}
\hline Pellet type groups & SS & DF & SA & F & Value-P & Fc & Significant effect \\
\hline $1 \mathrm{~cm} / 2 \mathrm{~cm}$ & 24.807 & 1 & 24.807 & 9.66 & 0.0359 & 7.71 & YES \\
$1 \mathrm{~cm} / 3 \mathrm{~cm}$ & 28.210 & 1 & 28.210 & 20.27 & 0.0108 & 7.71 & YES \\
$1 \mathrm{~cm} /$ Semi-sphere & 16.335 & 1 & 3.226 & 9.97 & 0.0342 & 7.71 & YES \\
$(2 \mathrm{~cm}$ in diameter $)$ & & &
\end{tabular}

Note: $\mathrm{SS}=$ Square Sum;

DF = Degrees of freedom;

$\mathrm{SA}=$ square average;

$\mathrm{F}=$ calculated value of $\mathrm{F}$;

Value - $P$ = Significance level;

$\mathrm{FC}=$ Critical $\mathrm{F}$; and

If $p<5 \%$ and $\mathrm{Fc}<\mathrm{F}$, the effect is significant, considering the $95 \%$ confidence interval.

Table 10 - Statistical confidence for clinkers with CCW-1 incorporation, produced with $1 \mathrm{~cm}, 2 \mathrm{~cm}, 3$ $\mathrm{cm}$ pellets, and $2 \mathrm{~cm}$ diameter semi-sphere, through analysis of variance (ANOVA)

\begin{tabular}{l|c|c|c|c|c|c|c}
\hline \multicolumn{1}{c}{ Pellet type groups } & SS & DF & SA & F & Value-P & Fc & Significant effect \\
\hline $1 \mathrm{~cm} / 2 \mathrm{~cm}$ & 24.64 & 1 & 24.64 & 34.94 & 0.0041 & 7.71 & YES \\
$1 \mathrm{~cm} / 3 \mathrm{~cm}$ & 11.40 & 1 & 11.40 & 10.02 & 0.0340 & 7.71 & YES \\
$1 \mathrm{~cm} /$ Semi-sphere $(2$ & 4.22 & 1 & 3.226 & 2.74 & 0.173 & 7.71 & NO \\
$\mathrm{cm}$ in diameter) & 4.22 & & & & \\
\hline
\end{tabular}

Note: SS = Square Sum;

DF = Degrees of freedom;

$\mathrm{SA}=$ square average;

$\mathrm{F}=$ calculated value of $\mathrm{F}$;

Value - $\mathrm{P}=$ Significance level;

$\mathrm{FC}=$ Critical $\mathrm{F} ;$ and

If $\mathrm{p}<5 \%$ and $\mathrm{Fc}<\mathrm{F}$, the effect is significant, considering the $95 \%$ confidence interval.

The specific surface area of $1 \mathrm{~cm}$ diameter pellets is, on average, approximately $2.57 \mathrm{~cm} / \mathrm{g}$, about 1.4 times greater than the specific surface area of $2 \mathrm{~cm}$ diameter pellets (on average, $1.90 \mathrm{~cm} / \mathrm{g}$ ), 2.1 times greater than the specific surface area of pellets with a diameter of $3 \mathrm{~cm}$ (on average, $1.23 \mathrm{~cm} / \mathrm{g}$ ) and $10 \%$ greater than that of semi-spherical pellets (on average $2.32 \mathrm{~cm} / \mathrm{g}$ ). Therefore, pellets with $1 \mathrm{~cm}$ diameter presents a better clinkering, due to their higher specific surface area, indicating that they are more reactive than pellets with other geometries and sizes. Specific surface area values are directly proportional to reactivity of clinkers (DINGER, 2005).

The average volume of pellets with $3 \mathrm{~cm}$ in diameter is $13.468 \mathrm{~cm}$, the average volume of pellets with $2 \mathrm{~cm}$ in diameter is $3.495 \mathrm{~cm}$, while the volume of pellets with $1 \mathrm{~cm}$ in diameter is $0.529 \mathrm{~cm}, 25.5$ and 6.6 times higher, respectively, which results in a higher heat demand for the same calcination conditions.

Thus, in pellets with $2 \mathrm{~cm}$ and $3 \mathrm{~cm}$ in diameter there is a greater difficulty of heat transfer during clinker under the same burning conditions when compared to pellets with $1 \mathrm{~cm}$ in diameter and half-sphere shape. This also affects the cooling of the clinkers, influencing the formation of crystalline phases, in these different pellet configurations.

Analyzing the amount of $\mathrm{C}_{3} \mathrm{~A}$ formed, it is clear that in clinkers with $\mathrm{CCW}-1$ incorporation there was a lower formation of cubic $\mathrm{C}_{3} \mathrm{~A}$ (contents of 6.7 to $7.5 \%$ ), when compared to reference clinkers and with $\mathrm{CCW}_{20-40}$. (contents of 9.3 to $11.6 \%$ ), probably because $\mathrm{CCW}-1$ has a lower content of $\mathrm{Al}_{2} \mathrm{O}_{3}$ compared to $\mathrm{CCW}_{20-40}(7.5 \%$ against 11.67 , as shown in Table 4$)$ and clay, used in the clinker of reference $(23.55 \%$ $\left.\mathrm{Al}_{2} \mathrm{O}_{3}\right)$.

Tricalcium aluminate $\left(\mathrm{C}_{3} \mathrm{~A}\right)$ is the clinker phase responsible for the initial hydration reactions. In the absence of gypsum, the formation of hydrated aluminates, both in the cubic and orthorhombic crystalline system, occurs immediately after mixing with water, however, the cubic $\mathrm{C}_{3} \mathrm{~A}$ is more reactive and releases more heat (KIRCHHEIM et al., 2010). Thus, the incorporation of CCW-1 may have a greater influence on cement hydration as is less reactive and may have a delayed setting time, in relation to the other types of clinker analyzed in this research. The content of orthorhombic $\mathrm{C}_{3} \mathrm{~A}$ varied slightly between the different clinkers and conformations of the spheres. 
From the analysis of the average contents of the crystalline phases alite, belite and free lime (Tables 6 and 7) in the experimental clinkers of reference and in the clinkers with the two types of CCW it was noticed that the main phases of the clinker were formed in similar contents to those indicated in the specialized literature to classify them as Portland clinker (50 to $70 \%$ alite) (TAYLOR, 1997). This was even with the different conformations of the pellets which it did not negatively affect its mineralogical characteristics. The $\mathrm{C}_{3} \mathrm{~S}$ content of clinkers is the most important indicator for controlling the development of the main properties of Portland cement (SCRIVENER; JUILLAND; MONTEIRO, 2015).

The amount of free lime in all dosages and in different conformations remained below $1 \%$, indicating that both the burning and the cooling were not affected when there was a change in the geometry of the pellets. It can also be noticed that the clinkers produced with the incorporation of $\mathrm{CCW}$ in total replacement of clay and partial of limestone had a higher alite content, when compared to the clinkers produced with traditional raw materials (limestone and clay). This demonstrates that the replacement is technically feasible, enabling lower $\mathrm{CO}_{2}$ emissions and less exploitation of natural resources.

\section{Conclusions}

From the results obtained in the present work, it can be concluded that:

(a) the incorporation of the $\mathrm{CCW}$ enabled the reduction in the use of up to $14 \%$ of limestone in the raw mix for the production of Portland clinker. Therefore, there would be a reduction in the extraction of this natural material;

(b) the specific surface area of the shaped pellets influences the formation of the alite and belite phases, due to differences in the exposure area, during sintering and cooling. Thus, we propose standardization of the size of the pellets for analysis purposes involving the production of clinker on a laboratory scale;

(c) although there are differences in the contents of the crystalline phases formed, due to the different conformations of the pellets, this did not negatively affect the mineralogical characteristics. This is because the content of the main clinker phases, remained within the values indicated in the specialized literature. to classify them as Portland clinker (50 to $70 \%$ alite);

(d) the use of molds standardizes and facilitates the making of clinkers, increasing the homogeneity of the material produced; and

(e) clinkers containing CCW in total replacement for clay and partial replacement for limestone presented a mineralogical composition similar to reference clinkers.

\section{References}

ALI, M. B.; SAIDUR, R.; HOSSAIN, M. S. A review on emission analysis in cement industries. Renewable and Sustainable Energy Reviews, v. 15, n. 5, p. 2252-2261, 2011.

AMORIM JÚNIOR, N. S. et al. Concrete containing recycled aggregates: Estimated lifetime using chloride migration test. Construction and Building Materials, v. 222, p. 108-118, 2019.

ANDRADE, R. D.; KIHARA, Y.; MARINGOLO, V. Incorporation of V, Zn and Pb into the crystalline phases of Portland clinker. Cement and Concrete Research, v. 33, n. 1, p. 63-71, 2003.

ASENSIO, E. et al. Characterization of ceramic-based construction and demolition waste: use as pozzolan in cements. Journal of the American Ceramic Society, v. 99, p. 4121-4127, 2016.

ASSOCIAÇÃO BRASILEIRA DE EMPRESAS DE LIMPEZA PÚBLICA E RESÍDUOS ESPECIAIS. Panorama dos resíduos sólidos no Brasil 2018/2019. 2020. http://abrelpe.org.br/download-panorama2018-2019/. Access: 11 Feb. 2020.

ASSOCIAÇÃO BRASILEIRA DE NORMAS TÉCNICAS. NBR 16697: cimento Portland: requisitos. Rio de Janeiro, 2018.

AY, N.; ÜNAL, M. The use of waste ceramic tile in cement production. Cement and Concrete Research, v. 30, n. 3, p. 497-499, 2000.

BEAUDOIN, J. J. Miniaturized techniques. In: RAMACHANDRAN, S.; BEAUDOIN, J. J. Handbook of analytical techniques in concrete science and technology principles, techniques and applications. Canada: V Noyes Publications, 2001. 
BOGAS, J. A.; CARRIÇO, A.; PEREIRA, M. F. C. Mechanical characterization of thermal activated low carbon recycled cement mortars. Journal Cleaner Production, v. 218, p. 377-389, 2019.

BRANDŠTETR, J.; HAVLICA, J.; ODLER, I. Properties and use of solid residue from fluidized bed coal combustion. In: CHANDRA S. (ed.). Waste materials used in concrete manufacturing. Westwood: Noyes Publications Press, 1997.

BROCH, E. Crystal Structure. Zeitschrift fuer Physikalische Chemie, v. 127, p. 446-454, 1927.

BUI, N. K.; SATOMI, T.; TAKAHASHI, H. Mechanical properties of concrete containing 100\% treated coarse recycled concrete aggregate. Construction and Building Materials, v. 163, p. 496-507, 2018.

BURUBERRI, L. H.; SEABRA, M. P.; LABRINCHA, J. A. Preparation of clinker from paper pulp industry wastes. Journal of Hazardous Materials, v. 286, p. 252-260, 2015.

CANTERO, B. et al. Inclusion of construction and demolition waste as a coarse aggregate and a cement addition in structural concrete design. Archives of Civil and Mechanical Engineering, v. 19, p. 1338-1352, 2019.

CHATTERJEE, A. K. Chemistry and engineering of the clinkerization process: incremental advances and lack of breakthroughs. Cement and Concrete Research, v. 41, n. 7, p. 624-641, 2011.

CHEN, Y.-L.; CHANG, J.-E.; KO, M.-S. Reusing desulfurization slag in cement clinker production and the influence on the formation of clinker phases. Sustainability, v. 9, paper 1585, 2017.

CONSELHO NACIONAL DO MEIO AMBIENTE. Resolução n. 307, diretrizes e procedimentos para gestão dos resíduos de construção. Brasília, 2002.

COSTA, E. B. da. Using aluminum anodizing waste in the production of calcium sulfoaluminate belite cement. Porto Alegre, 2013. Thesis (Master's degree) - Escola de Engenharia, Universidade Federal do Rio Grande do Sul, Porto Alegre, 2013.

COSTA, E. B. et al. Portland cement clinker with reduced environmental impact. Ambiente Construído, Porto Alegre, v. 13, n. 2, p. 75-86, abr./jun. 2013.

COSTA, E. B. et al. Production and hydration of calcium sulfoaluminate-belite cements derived from aluminium anodising sludge. Construction and Building Materials, v. 122, p. 373-383, 2016.

COUVILLE, A. A.; GELLER, S. The crystal structure of brownmillerite $\mathrm{Ca}_{2} \mathrm{FeAlO}_{5}$. Acta Crystallographica B, v. 27, p. 2311-2315, 1971.

DINGER, D. R. Characterization techniques for ceramists. Clemson: Dennis Dinger, 2005.

FAURE, A. et al. Beneficial reuse of dam fine sediments as clinker raw material. Construction and Building Materials, v. 218, p. 365-384, 2019.

GALBENIS, C. T.; TSIMAS, S. Use of construction and demolition wastes as raw materials in cement clinker production. China Particuology, v. 4, n. 2, p. 83-85, 2006.

GARTNER, E.; SUI, T. Alternative cement clinkers. Cement and Concrete Research, v. 114, p. 27-39, 2018.

GOMES, A. G. et al. mineralogical analysis of portland clinker produced from the incorporation of Granitic Rock Fines (GRF). Key Engineering Materials, v. 803, p. 309-313, 2019.

GUO, H. et al. Durability of recycled aggregate concrete: a review. Cement Concrete Composite, v. 89, p. 251-259, 2018.

JOST, K. H.; ZIEMER, B.; SEYDEL, R. Redetermination of the structure of dicalcium silicate. Acta Crystallographica B, v. 33, p. 1696-1700, 1977.

KIM, J.; TAE, S.; KIM, R. Theoretical study on the production of environment-friendly recycled cement using inorganic construction wastes as secondary materials in South Korea. Sustainability, v. 10, paper 4449, 2018.

KIM, Y. J.; CHOI, Y. W. Utilization of waste concrete powder as a substitution material for cement. Construction and Building Materials, v. 30, p. 500-504, 2012.

KIRCHHEIM, A. P. et al. Alkalis incorporated into tricalcium aluminate: effects in hydration. Ambiente Construído, Porto Alegre, v. 10, n. 1, p. 177-189, jan./mar. 2010. 
KOLOVOS, K. et al. The effect of foreign ions on the reactivity of the $\mathrm{CaO}-\mathrm{SiO}_{2}-\mathrm{Al}_{2} \mathrm{O}_{3}-\mathrm{Fe}_{2} \mathrm{O}_{3}$ system. Cement and Concrete Research, v. 31, n. 3, p. 425-429, 2001.

LETELIER, V. et al. Combined effects of recycled hydrated cement and recycled aggregates on the mechanical properties of concrete. Construction and Building Materials, v. 132, p. 365-375, 2017.

LUDWIG, H.-M.; ZHANG, W. Research review of cement clinker chemistry. Cement and Concrete Research, v. 78, part A, p. 24-37, dec. 2015.

MARIANI, B. B. et al. Effect of the incorporation of $\mathrm{TiO}_{2}$ waste (UOW) in the formation of the mineralogical phases of Portland clinker. Ambiente Construído, Porto Alegre, v. 19, n. 1, p. 57-71, jan./mar. 2019.

MONDAL, P.; JEFFERY, J. W. The crystal structure of Tricalcium Aluminate, $\mathrm{Ca}_{3} \mathrm{Al}_{2} \mathrm{O}_{6}$. Acta Cristallographica B, v. 31, p. 689-697, 1975.

NISHI, F.; TAKEUCHI, Y. The $\mathrm{Al}_{2} \mathrm{O}_{18}$ rings of tetrahedra in the structure of $\mathrm{Ca}_{8.5} \mathrm{NaAl}_{6} \mathrm{O}_{18}$. Acta Cristallographica B, v. 31, p. 1169-1173, 1975.

NISHI, F.; TAKEUCHI, Y.; MAKI, I. Tricalcium Silicate, $\mathrm{Ca}_{3} \mathrm{O}\left(\mathrm{SiO}_{4}\right)$ : the monoclinic superstruture. Zeitschrift fuer Kristallographie, v. 172, p. 297-314, 1985.

NOBRE, T. R. S.; GUERREIRO, A. Q.; KIRCHHEIM, A. P. Concrete yesterday: cement tomorrow. Concrete \& Constructions, v. 77, p. 34-40, 2015.

PRIMAK, W.; KAUFMAN, H.; WARD, R. X-ray diffraction studies of systems involved in the preparation of alkaline earth sulfide and selenide phosphors. Journal of the American Chemical Society, v. 70, p. 2043-2046, 1948.

PUERTAS, F. et al. Ceramic wastes as alternative raw materials for Portland cement clinker production. Cement and Concrete Composites, v. 30, p. 798-805, 2008.

PUERTAS, F. et al. Ceramic wastes as raw materials in Portland cement clinker fabrication: characterization and alkaline activation. Materiales de Construcción, v. 56, 281, p. 73-84, 2006.

PUERTAS, F. et al. Clinkers and cements obtained from raw mix containing ceramic waste as a raw material: characterization, hydration and leaching studies. Cement and Concrete Composites, v. 30, p. 798-805, 2010.

RAINA, K.; JANAKIRAMAN, L. K. Use of mineralizer in black meal process for improved clinkerization and conservation of energy. Cement and Concrete Research, v. 28, n. 8, p. 1093-1099, 1998.

REN, C. et al. Complementary use of industrial solid wastes to produce green materials and their role in $\mathrm{CO}_{2}$ reduction. Journal of Cleaner Production, v. 252, paper 119840, 2020.

RODRÍGUEZ, N. H. et al. The effect of using thermally dried sewage sludge as an alternative fuel on Portland cement clinker production. Journal of Cleaner Production, v. 52, p. 94-102, 2013.

RUIZ-SÁNCHEZ, A.; SÁNCHEZ-POLO, M.; ROZALEN, M. Waste marble dust: an interesting waste to produce cement. Construction and Building Materials, v. 224, p. 99-108, 2019.

$\mathrm{SCHOON}$, J. et al. Fines extracted from recycled concrete as alternative raw material for Portland cement clinker production. Cement and Concrete Composites, v. 58, p. 70-80, 2015 Apr. 2015.

SCRIVENER, K. L.; JOHN, V. M.; GARTNER, E. M. Eco-efficient cements: potential economically viable solutions for a low- $\mathrm{CO}_{2}$ cement-based materials industry. Cement and Concrete Research, v. 114, p. 2-26, 2018.

SCRIVENER, K. L.; JUILLAND, P.; MONTEIRO, J. M. M. Advances in understanding hydration of Portland cement. Cement and Concrete Research, v. 78, p. 38-56, 2015.

SHAH, V.; BISHNOI, S. Use of marble dust as clinker replacement in cements. Indian Concrete Journal, v. 89 , n. 1, p. 27-32, 2015.

SILVA, G. A. O. Evaluation of durability on concrete containing recycled aggregates from construction and demolition waste (CDW). Salvador, 2017. Thesis (Master's degree) - Pos-Graduação em Engenharia Civil, Universidade Federal da Bahia, Salvador, 2017.

SIMÃO, L. et al. Thermal characterization of hydrated eco-friendly clinkers produced from pulp and paper mill waste. Cerâmica, v. 64, p. 311-317, 2018. 
SNELLINGS, R. A practical guide to microstructural analysis of cementitious materials. New York: Taylor \& Francis, 2016.

TAYLOR, H. F. W. Cement chemistry. $2^{\text {nd }}$. ed. London: Thomas Telford, 1997.

TREZZA, M. A.; SCIAN, A. N. Waste with chrome in the Portland cement clinker production. Journal of Hazardous Materials, v. 147, n. 1/2, p. 188-196, 2007.

TSAKIRIDIS, P. E.; SAMOUHOS, M.; PERRAKI, M. Valorization of Dried Olive Pomace as an alternative fuel resource in cement clinkerization. Construction and Building Materials, v. 153, p. $202-$ 210, 2017.

TSAKIRIDIS, P. et al. Utilization of steel slag for Portland cement clinker production. Journal of Hazardous Materials, vol. 152, n. 2, p. 805-811, 2008.

UNITED STATES GEOLOGICAL SURVEY. Cement mineral commodity summary 2019. 2019. Available: https://minerals.usgs.gov/minerals/pubs/commodity/cement/mcs-2019-cemen.pdf. Access: 05 fev. 2020.

VILAPLANA, A. S. G. et al. Utilization of Ladle Furnace slag from a steelwork for laboratory scale production of Portland cement. Construction and Building Materials, v. 94, n. 30, p. 837-843, 2015.

WALENTA, G.; FÜLLMANN, T. Advances in quantitative XRD analysis for clinker, cements, and cementitious additions. International Centre for Diffraction, Advances in X-ray Analysis, v. 47, p. 287296, 2004.

WINTER, N. B. Understanding cement: an introduction to cement production, cement hydration and deleterious process in concrete. Woodbridge, 2012. WHD Microanalyses Consultants.

YOUNG, G.; YANG, M. Preparation and characterization of Portland cement clinker from iron ore tailings. Construction and Building Materials, v. 197, p. 152-156, 2019.

\title{
Acknowledgements
}

The authors would like to thank FAPESB-Bahia Research Foundation, PPEC / UFBA, and UFRB. Also, the Waste Recovery Unit Grajau S.A. (WRUG) and the cement company, for the donation of materials, and the Structures Laboratory (Timoshenko) / UFBA, Materials Laboratory Construction of Feira de Santana State University (UEFS) and Federal Institute of Education of Bahia (IFBA) for allowing us to use their equipment in tests external to LEDMa / UFBA.

Fernanda Nepomuceno Costa

Programa de Pós-Graduação em Engenharia Civil, Escola Politécnica | Universidade Federal da Bahia | Rua Aristides Novis, $2,3^{\circ}$ andar, Federação | Salvador - BA - Brasil | CEP 40210-630 | Tel.: (71) 3283-9593 | E-mail: fernandacosta@ufrb.edu.br

\section{Daniel Véras Ribeiro}

Departamento de Ciência e Tecnologia dos Materiais, Escola Politécnica | Universidade Federal da Bahia | E-mail: verasribeiro@hotmail.com

\section{Cléber Marcos Ribeiro Dias}

Departamento de Ciência e Tecnologia dos Materiais, Escola Politécnica | Universidade Federal da Bahia | E-mail: clebermrd@gmail.com

\author{
Ambiente Construído \\ Revista da Associação Nacional de Tecnologia do Ambiente Construído \\ Av. Osvaldo Aranha, $99-3^{\circ}$ andar, Centro \\ Porto Alegre - RS - Brasil \\ CEP $90035-190$ \\ Telefone: +55 (51) 3308-4084 \\ Fax: +55 (51) 3308-4054 \\ www.seer.ufrgs.br/ambienteconstruido \\ E-mail: ambienteconstruido@ufrgs.br
}

This is an open-access article distributed under the terms of the Creative Commons Attribution License. 